\title{
Foliar Application of Zinc Oxide Nanoparticles Promotes Drought Stress Tolerance in Eggplant (Solanum melongena L.)
}

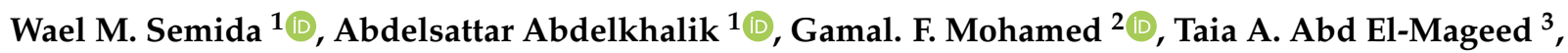 \\ Shimaa A. Abd El-Mageed ${ }^{4}$, Mostafa M. Rady ${ }^{2, * \mathbb{D}}$ and Esmat F. Ali ${ }^{5}$ (D) \\ 1 Horticulture Department, Faculty of Agriculture, Fayoum University, Fayoum 63514, Egypt; \\ wms00@fayoum.edu.eg (W.M.S.); aga04@fayoum.edu.eg (A.A.) \\ 2 Botany Department, Faculty of Agriculture, Fayoum University, Fayoum 63514, Egypt; \\ gfm00@fayoum.edu.eg \\ 3 Soil and Water Department, Faculty of Agriculture, Fayoum University, Fayoum 63514, Egypt; \\ taa00@fayoum.edu.eg \\ 4 Agronomy Department, Faculty of Agriculture, Fayoum University, Fayoum 63514, Egypt; \\ sa1944@fayoum.edu.eg \\ 5 Department of Biology, College of Science, Taif University, P.O. Box 11099, Taif 21944, Saudi Arabia; \\ a.esmat@tu.edu.sa \\ * Correspondence: mmr02@fayoum.edu.eg; Tel.: +2-084-010-923-920-38
}

\section{check for} updates

Citation: Semida, W.M.; Abdelkhalik, A.; Mohamed, G..F.; Abd El-Mageed, T.A.; Abd El-Mageed, S.A.; Rady, M.M.; Ali, E.F. Foliar Application of Zinc Oxide Nanoparticles Promotes Drought Stress Tolerance in Eggplant (Solanum melongena L.). Plants 2021, 10, 421. https://doi.org/10.3390/ plants10020421

Academic Editor: Brigitta Tóth

Received: 29 January 2021

Accepted: 21 February 2021

Published: 23 February 2021

Publisher's Note: MDPI stays neutral with regard to jurisdictional claims in published maps and institutional affiliations.

Copyright: (c) 2021 by the authors. Licensee MDPI, Basel, Switzerland. This article is an open access article distributed under the terms and conditions of the Creative Commons Attribution (CC BY) license (https:/ / creativecommons.org/licenses/by/ $4.0 /)$.

\begin{abstract}
Water shortage and salinity are major challenges for sustaining global food security. Using nutrients in the nano-scale formulation including zinc oxide nanoparticles ( $\mathrm{ZnO} N P$ ) is a novel fertilization strategy for crops. In this study, two field-based trials were conducted during 2018 and 2019 to examine the influence of three $\mathrm{ZnO}$ NP concentrations (0, 50, and $100 \mathrm{ppm}$ ) in eggplant grown under full irrigation (100 of crop evapotranspiration; ETc) and drought stress (60\% of ETc). Plant growth, yield, water productivity (WP), physiology, biochemistry, and anatomy responses were evaluated. Drought stress significantly decreased membrane stability index (MSI), relative water content (RWC), and photosynthetic efficiency, thus hampered eggplant growth and yield. In contrast, exogenous ZnO NP to water-stressed eggplant resulted in increased RWC and MSI associated with improved stem and leaf anatomical structures and enhanced photosynthetic efficiency. Under drought stress, supplementation of 50 and 100 ppm ZnO NP improved growth characteristics and increased fruit yield by $12.2 \%$ and $22.6 \%$, respectively, compared with fully irrigated plants and nonapplied $\mathrm{ZnO}$ NP. The highest water productivity (WP) was obtained when eggplant was irrigated with $60 \%$ ETc and foliarly treated with 50 or 100 ppm of ZnO NP, which led to 50.8-66.1\% increases in WP when compared with nontreated fully irrigated plants. Collectively, these findings demonstrated that foliar spraying ZnO NP gives the utility for alleviating drought stress effects on eggplant cultivated in saline soil.
\end{abstract}

Keywords: zinc oxide nanoparticles; deficit irrigation; water productivity; photosynthetic efficiency; growth and productivity

\section{Introduction}

Sustainable agricultural development depends on the type and supply of irrigation water worldwide, given that agriculture consumes approximately $69 \%$ of the total freshwater [1]. Universally, water and food production is closely related, with nearly $40 \%$ of agricultural production around the world coming from irrigated cropland [2]. In the Mediterranean region, water resources are scarce, which calls for the need to reassess current water use practices. The increasing population growth leads to an increase in the demand for food, which increases the irrigated area, which has increased eight-fold over the past century [3-5]. These restrictions and risks to food security will be massive, particularly with the expected climate change, causing increased competition for water resources 
between different sectors [6,7]. To weaken global changes in the future and ensure food security, many attempts are being made through investigations to boost water productivity (WP). Therefore, effective innovations in irrigation and management techniques are needed to achieve more efficient and logical use of water [8-12]. In this concern, deficit irrigation (DI) is used as a practice to save water by adding less water than the irrigation water requirement $[3,13]$.

Eggplant (Solanum melongena L.) is a distinct crop worldwide, with a cultivated area of 1.86 million ha, producing approximately 54 million Mg. Globally, Egypt ranked third of the largest eggplant producers accounting approximately $2.6 \%$ of the world's production [14]. Eggplant required uniform soil moisture for obtaining important marketable yield $[15,16]$. Although eggplant was considered to be moderately tolerant to water stress [17], it is difficult to apply water deficits, especially in arid and semiarid areas with saline soil without yield reduction. Withholding irrigation to four varieties of eggplant strongly reduced the fresh weight of different plant parts (roots, stem, and leaves) and leaf water content as well as decreased chlorophyll content [18]. Eggplant fruit yield decreased up to $60 \%$ when water deficits increased from $20 \%$ to $40 \%$ of the field capacity [19]. Deficiencies in nutrients absorption and transport due to water stress, resulted in loss of crop yield. Further, under alkaline soil conditions, the absorption and transfer of nutrients from the roots to the leaves decrease, especially microelements [20].

Zinc (Zn) is a micro-nutrient having important roles in the growth of all crop plants. $\mathrm{Zn}$ is involved in the activity of various enzymes (RNA and DNA polymerases, dehydrogenases, transphosphorylases, and proteinase), as well as contributes to the maintenance of the membrane structure and cell division, chlorophyll biosynthesis, and improves plant photosynthetic apparatus [20-22]. Foliar-applied microelements are more convenient for plant response at the field scale, as it is environmentally friendly compared to soil application which may show toxicity upon adding the same microelements [21,23]. Micronutrients have been shown to alleviate water stress in plants by enhancing WP, maintaining cell integrity, and detoxifying drought-induced free radicals [24,25].

In recent years, the incorporation of nanomaterials products in many sectors including nanofertilizers is gaining interest. Nanoparticles (NP) have novel properties as a result of their small size (below $100 \mathrm{~nm}$ at least in one dimension) which results in high surface areas and surface charges, therefore, NP are more reactive than their bulk scale counterparts $[25,26]$. Nanofertilizers are used to gradually release nutrients while minimizing soil pollution [27]. These nanoscale fertilizers are an approach that makes nutrients available to plant leaves, thus increasing the efficiency of plant nutrient uptake [28]. ZnO NP have been reported to alleviate oxidative damage in various crops [29-31]. ZnO NP reduced malondialdehyde (MDA) level and enhanced CAT and SOD activities in stressed Leucaena leucocephala [30]. Similar results were also reported by in green pea and sugar beet [31]. One of the benefits of nanoscale fertilizers is to minimize the addition rate of nutrients, thus saving the input costs and sustainably minimizing the environmental footprint of chemical fertilizers [32]. Due to their small size, nanofertilizers have a higher and faster translocation between plant parts, which increases nutrient efficiency [33].

Conventional $\mathrm{Zn}$ fertilizer in the form of $\mathrm{ZnSO}_{4} \cdot 7 \mathrm{H}_{2} \mathrm{O}$ has a very low $\mathrm{Zn}$ use efficiency $(1-5 \%)$. However, zinc oxide nanoparticles ( $\mathrm{ZnO} \mathrm{NP})$ are systematically evaluated in plants to enhance their ability to modulate crop productivity and nutrient use efficiency [32]. It has been previously demonstrated that using nanofertilizers has the potential to promote drought stress tolerance in several crops; soybean [20], maize [34], and wheat [32]. According to [22], spraying ZnO NP only or in combination with $\mathrm{Cu}$ NP and Mn NP increased basil plant growth, chlorophyll content, as well as enhanced antioxidant activity. ZnO NP amended drought-stressed sorghum plant, increased green yield up to $183 \%$, and improved total $\mathrm{N}$ and $\mathrm{K}$ acquisition by the plant [25].

A combination of deficit irrigation and the application of nanofertilizers may have the potential to provide significant water-savings and improve the WP in eggplant. At the field scale, eggplant responses to combined deficit irrigation and foliar application of $\mathrm{ZnO}$ 
NP grown under salt-alkaline soil are not yet fully investigated. Therefore, this research aimed to explore the potential effect of foliar-applied $\mathrm{ZnO}$ NP to ameliorate the drought stress on eggplant. Further, studying their impact on eggplant growth, yield, WP, tissue water status, photosynthetic efficiency, nutrients contents, and anatomical responses.

\section{Materials and Methods}

\subsection{Experimental Site}

Two trials were consecutively conducted during the summer season of 2018 and 2019 (5 April to 29 August) at El Fayoum region (latitudes $29^{\circ} 02^{\prime}$ and $29^{\circ} 35^{\prime} \mathrm{N}$ and longitudes $30^{\circ} 23^{\prime}$ and $31^{\circ} 05^{\prime} \mathrm{E}$ ), Egypt. Average climatic data of this region during the two growing seasons are given in Table 1. A typic torripsamment, siliceous, hyperthermic, loamy sand [35], and its physicochemical characteristics were evaluated [36,37] and displayed in Tables 2 and 3.

Table 1. Weather data at Fayoum area, Egypt during the growing season.

\begin{tabular}{|c|c|c|c|c|c|}
\hline \multirow{2}{*}{ Month } & \multicolumn{2}{|c|}{ Main Temperatures $\left({ }^{\circ} \mathrm{C}\right)$} & \multirow{2}{*}{$\begin{array}{c}\text { RHavg } \\
\%\end{array}$} & \multirow{2}{*}{$\begin{array}{c}\mathrm{U}_{2} \\
\mathrm{~ms}^{-1}\end{array}$} & \multirow{2}{*}{$\begin{array}{c}\text { Ep } \\
\text { mmd }^{-1}\end{array}$} \\
\hline & Day & Night & & & \\
\hline April & 33.36 & 15.92 & 30.00 & 1.93 & 5.60 \\
\hline May & 36.50 & 19.52 & 31.00 & 1.90 & 6.90 \\
\hline June & 39.40 & 20.30 & 36.00 & 1.50 & 7.60 \\
\hline July & 40.36 & 25.90 & 36.00 & 2.10 & 6.90 \\
\hline August & 40.40 & 26.30 & 37.00 & 1.80 & 6.80 \\
\hline
\end{tabular}

$\mathrm{RH}_{\text {avg }}$ is average relative humidity, $\mathrm{U}_{2}$ is average wind speed, and $E_{P}$ is average of measured pan evaporation class $\mathrm{A}$.

Table 2. Some initial physical properties of the experimental soil.

\begin{tabular}{|c|c|c|c|c|c|c|c|c|c|}
\hline \multirow[b]{2}{*}{ Layer $(\mathrm{cm})$} & \multicolumn{4}{|c|}{ Particle Size Distribution } & \multirow{2}{*}{$\begin{array}{c}\text { Bulk } \\
\text { Density } \\
\left(\mathrm{g} \mathrm{cm}^{-3}\right)\end{array}$} & \multirow{2}{*}{$\begin{array}{c}\mathrm{K}_{\text {sat }} \\
\mathrm{cm} \mathrm{h}^{-1}\end{array}$} & \multirow{2}{*}{$\begin{array}{l}\text { FC } \\
(\%)\end{array}$} & \multirow{2}{*}{$\begin{array}{l}\text { WP } \\
(\%)\end{array}$} & \multirow{2}{*}{$\begin{array}{l}\text { AW } \\
(\%)\end{array}$} \\
\hline & $\begin{array}{c}\text { Sand } \\
\%\end{array}$ & $\begin{array}{c}\text { Silt } \\
\%\end{array}$ & $\begin{array}{c}\text { Clay } \\
\%\end{array}$ & Texture Class & & & & & \\
\hline $0-25$ & 73.2 & 14. 0 & 12.8 & LS & 1.52 & 1.89 & 27.33 & 11.73 & 15.60 \\
\hline $25-50$ & 71.2 & 13.1 & 15.7 & LS & 1.47 & 1.55 & 26.19 & 11.13 & 15.06 \\
\hline
\end{tabular}

$\mathrm{FC}=$ field capacity, $\mathrm{WP}=$ wilting point, $\mathrm{AW}=$ available water, $\mathrm{LS}=$ loamy sand, and $\mathrm{K}_{\text {sat }}=$ hydraulic conductivity.

Table 3. Some initial chemical properties of the experimental soil.

\begin{tabular}{|c|c|}
\hline Properties & Value \\
\hline $\mathrm{pH}($ at a soil: water $(w / v)$ ratio of $1: 2.5)$ & 7.72 \\
\hline ECe $\left(\mathrm{dS} \cdot \mathrm{m}^{-1} ;\right.$ soil-paste extract $)$ & 7.33 \\
\hline $\mathrm{CEC}\left(\mathrm{cmol}_{\mathrm{e}} \mathrm{kg}^{-1}\right)$ & 11.15 \\
\hline $\mathrm{CaCO}_{3}(\%)$ & 4.85 \\
\hline Organic matter $(\%)$ & 1.12 \\
\hline ESP (exchangeable sodium percentage) & 10.62 \\
\hline \multicolumn{2}{|c|}{ Available Nutrients: } \\
\hline $\mathrm{N}(\%)$ & 0.03 \\
\hline $\mathrm{P}\left(\mathrm{mg} \mathrm{kg}^{-1}\right.$ soil $)$ & 511.8 \\
\hline $\mathrm{K}\left(\mathrm{mg} \mathrm{kg}^{-1}\right.$ soil $)$ & 65.9 \\
\hline $\mathrm{Fe}\left(\mathrm{mg} \mathrm{kg}^{-1}\right.$ soil $)$ & 3.54 \\
\hline $\operatorname{Mn}\left(\mathrm{mg} \mathrm{kg}^{-1}\right.$ soil) & 9.6 \\
\hline $\mathrm{Zn}\left(\mathrm{mg} \mathrm{kg}^{-1}\right.$ soil) & 0.60 \\
\hline $\mathrm{Cu}\left(\mathrm{mg} \mathrm{kg}^{-1}\right.$ soil) & 0.51 \\
\hline
\end{tabular}




\subsection{Experimental Design and Treatment Applications}

The arrangement of the trial was a split-plot system in a randomized complete block design (RCBD) with three replicates. Twice irrigation regimes (full irrigation, FI (100\% of crop evapotranspiration; ETc) and deficit irrigation, DI (60\% of ETc)) were applied to the main plots and the subplots with three $\mathrm{ZnO} N P$ concentrations $(0,50$, and $100 \mathrm{ppm})$ that were foliarly applied at two times; 30 days after transplanting and 2 weeks later. Thus, six treatments were used as follows: $\mathrm{I}_{100}\left(100 \%\right.$ of ETc), $\mathrm{I}_{60}\left(60 \%\right.$ of ETc), $\mathrm{I}_{100}+\mathrm{ZnO} \mathrm{NP} 50$ (50 ppm nanoscale $\mathrm{ZnO}), \mathrm{I}_{100}+\mathrm{ZnO} \mathrm{NP}_{100}\left(\mathrm{I}_{100}+100 \mathrm{ppm}\right.$ nanoscale $\left.\mathrm{ZnO}\right), \mathrm{I}_{60}+\mathrm{ZnO}$ $\mathrm{NP}_{50}$, and $\mathrm{I}_{60}+\mathrm{ZnO} \mathrm{NP}{ }_{100}$. Figure 1 shows the TEM image of $\mathrm{ZnO}$ nanoparticles ( $\mathrm{ZnO} \mathrm{NP})$.

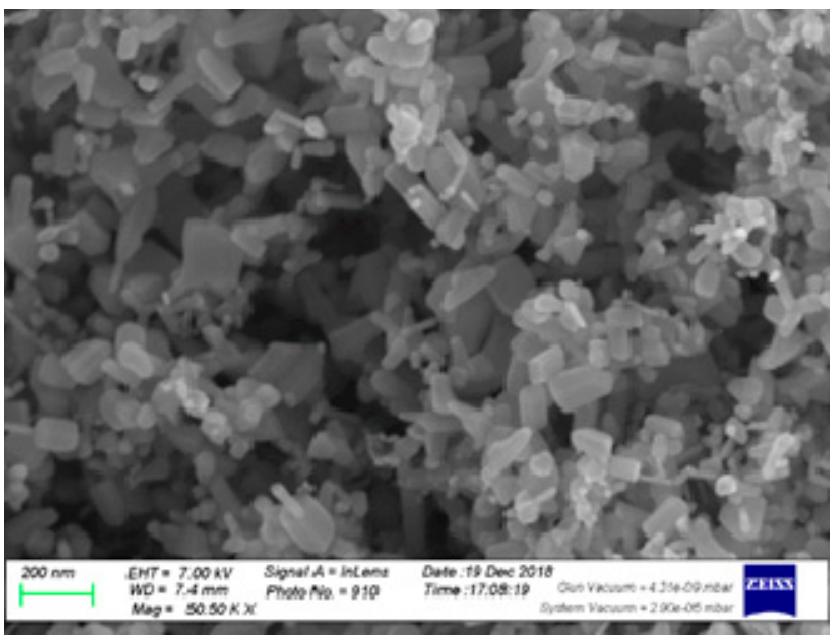

Figure 1. TEM image of $\mathrm{ZnO}$ nanoparticles ( $\mathrm{ZnO} \mathrm{NP}$ ).

The experimental area was divided into plots. The area of each plot was $15 \mathrm{~m}$ long $\times$ $0.70 \mathrm{~m}$ row width $\left(10.5 \mathrm{~m}^{2}\right)$. Plants were spaced about $30 \mathrm{~cm}$ between every two plants in rows, each row containing 50 plants. Eggplant transplants (cv. hybrid Soma ${ }^{\circledR}$ ) of 30 days old, secured from nurseries of the Ministry of Agriculture, were transplanted at a rate of one per emitter. The drip irrigation system was assigned at one line and one dripper for each plant, giving $3.6 \mathrm{~L}$ of saline irrigation water $\left(1.88 \mathrm{dS} \mathrm{m}^{-1}\right.$; Table 4) per hour. Seedlings were transplanted on 5 April and the trial was ended on 29 August, (in both seasons). Nonirrigated areas $3 \mathrm{~m}$ wide were designated as separation boundaries between each two irrigation treatments. Seven days after the transplanting, irrigation treatments were started. The agronomic practices for commercial eggplant crop production, including pest, weed, and disease control were followed as recommended.

Table 4. Chemical composition of irrigation water.

\begin{tabular}{|c|c|c|c|c|c|c|c|c|c|c|}
\hline \multicolumn{8}{|c|}{ Ionic Concentration (Meq $\mathrm{L}^{-1}$ ) } & \multirow{2}{*}{$\begin{array}{c}E C^{a} \\
\left(\mathrm{dS} \mathrm{m}^{-1}\right)\end{array}$} & \multirow{2}{*}{$\mathrm{pH}$} & \multirow{2}{*}{ SAR $^{b}$} \\
\hline $\mathrm{CO}_{3}{ }^{2-}$ & $\mathrm{HCO}_{3}^{-}$ & $\mathrm{Cl}^{-}$ & $\mathrm{SO}_{4}{ }^{2-}$ & $\mathrm{Ca}^{2+}$ & $\mathrm{Mg}^{2+}$ & $\mathrm{Na}^{+}$ & $\mathrm{K}^{+}$ & & & \\
\hline 0.00 & 2.8 & 10.8 & 5.4 & 5.0 & 4.3 & 8.4 & 1.3 & 1.88 & 7.37 & 3.99 \\
\hline
\end{tabular}




\subsection{Irrigation Water Applied (IWA)}

Eggplant seedlings were watered with different quantities of irrigation water at intervals of 2 days till the end of trial. The water requirements of the crop (ETc) were given as determined using class A pan equation [38]:

$$
\mathrm{ET}_{\mathrm{c}}=\mathrm{E}_{\mathrm{pan}} \times \mathrm{K}_{\mathrm{pan}} \times \mathrm{K}_{\mathrm{c}}
$$

where ETc is the crop water requirement $\left(\mathrm{mm} \mathrm{day}^{-1}\right), \mathrm{E}_{\mathrm{pan}}$ is the evaporation from the Class A pan $\left(\mathrm{mm} \mathrm{day}^{-1}\right), \mathrm{K}_{\mathrm{pan}}$ the Pan coefficient [38], and $\mathrm{K}_{\mathrm{c}}$ is the crop coefficient.

Irrigation water application (IWA) was determined by using the following formula:

$$
\mathrm{IWA}=(\mathrm{A} \times \mathrm{ETc} \times \mathrm{Ii} \times \mathrm{Kr}) \div[\mathrm{Ea} \times 1000 \times(1-\mathrm{LR})]
$$

where IWA = irrigation water applied in $\mathrm{m}^{3}, \mathrm{Ea}=$ application efficiency $\%, \mathrm{LR}=$ leaching requirements, $\mathrm{A}=$ plot area in $\mathrm{m}^{2}, \mathrm{ETc}=$ crop water requirements in $\mathrm{mm}$ per day, $\mathrm{Ii}=$ irrigation intervals (day), and $\mathrm{Kr}=$ covering factor.

\subsection{Measurements}

At the end of the trial, 10 plants were taken, randomly, from every experimental plot and assessed for growth characteristics. The fourth fully expanded leaves from the apex of stem (and its internodes) which emerged after drought imposition were taken per plant for assessing the morphological, physiological, macro and micronutrients and anatomical parameters.

\subsubsection{Morphological Parameters and Yield and its Components}

Plant height, stem diameter, and shoot fresh and dry weight were recorded $(\mathrm{cm})$ at the end of the trial. Plant leaf area $\left(\mathrm{cm}^{2}\right)$ was measured using the relationship of leaf area-leaf weight as demonstrated by [36] withsome modifications. Leaf surface was thoroughly washed in running tap water followed by washing with double-distilled water, thereafter $10-20$ leaf disks $\left(10-20 \mathrm{~cm}^{2}\right)$ were dried in an oven at $85^{\circ} \mathrm{C}$ for $24 \mathrm{~h}$ to get disks dry weight (DDW). Total leaf area plant ${ }^{-1}$ was calculated using the following formula:

$$
\text { Total leaf area plant }{ }^{-1}=(\mathrm{LDW} \div \mathrm{DDW}) \times \mathrm{DA}
$$

where LDW is the total leaf dry weight (g), DDW is the disks dry weight (g), and DA is the discs area.

A total of 50 days after transplanting, five plants were specified from each experimental plot to weekly record the average of fruit length $(\mathrm{cm})$, number of fruits plant ${ }^{-1}$, fruit weight (g), and total yield $\left(\mathrm{t} \mathrm{ha}^{-1}\right)$.

\subsubsection{Physiological Measurements}

Relative water content percentage (RWC, \%) was determined based on fresh (FM in $\mathrm{g}$ ), turgid (TM in g), and dry weights (DM in g) of leaf discs. After measuring FM of fresh leaves discs, they were placed into containers (slightly longer than the sample) with distilled for $24 \mathrm{~h}$ until a constant weight (the adhering water of the leaves was botted with absorbent paper toweling). TM was measured for each sample. DM was obtained after drying these leaves at $70{ }^{\circ} \mathrm{C}$ in an oven for $72 \mathrm{~h}$ to a constant weight. Relative water content percentage (RWC, \%) was determined following the [39] equation:

$$
\operatorname{RWC}(\%)=[(\mathrm{FM}-\mathrm{DM}) \div(\mathrm{TM}-\mathrm{DM})] \times 100
$$

Based on the electrical conductivity of two leaf samples devoid of midribs, heated at two different temperatures, 40 and $100{ }^{\circ} \mathrm{C}$ for 30 and $10 \mathrm{~min}(\mathrm{C} 1$ and $\mathrm{C} 2)$, respectively, the percentage of membrane stability index (MSI, \%) was determined following the [40] equation:

$$
\text { MSI }(\%)=[1-(\mathrm{C} 1 \div \mathrm{C} 2)] \times 100
$$


A portable fluorometer (Handy PEA, Hansatech Ltd., Kings Lynn, UK) was used to assess chlorophyll ' $a$ ' fluorescence. The equation $F_{v} / F_{m}=\left(F_{m}-F_{0}\right) \div F_{m}$ [41] was practiced to calculate the PSII maximum quantum yield. Based on the equal absorption, the equation included in [42] was also practiced to calculate the index of photosynthetic performance (PIABS). SPAD meter (SPAD-502-2900) was used to measure relative chlorophyll index of the eggplant. Possessing a 0.98 emissivity and a spectral response range of $8-14 \mu \mathrm{m}$, an infrared thermometer (Fluk 574, Everett, WA, USA) was functioned to perform the measurements of the canopy temperature.

Water productivity (WP) was calculated as mentioned in [43]:

$$
\mathrm{WP}=\left[\text { fruit yield }\left(\mathrm{kg} \mathrm{ha}^{-1}\right)\right] \div\left[\text { water applied }\left(\mathrm{m}^{3} \mathrm{ha}^{-1}\right)\right]
$$

\subsection{Macro- and Micronutrients Assessments}

The assessments of plant tissue contents of nutrients, N, P, K, Fe, Mn, and Zn were assessed in dry, fine ground eggplant leaves $(n=10)$. A micro-Kjeldahl (Medic. Instr. Co., Ningbo, China) apparatus was functioned to determine $\mathrm{N}$ content following the methods in [44]. Based on the method in [45], $\mathrm{P}$ content was assessed with molybdenum blue, $\mathrm{H}_{2} \mathrm{MoO}_{7} \mathrm{~S}, 8 \%(w / v) \mathrm{NaHSO}_{3}-\mathrm{H}_{2} \mathrm{SO}_{4}$, and diluted $\mathrm{H}_{2} \mathrm{MoO}_{7} \mathrm{~S}$ as standard reagents. An Atomic Absorption Spectrophotometer (Perkin-Elmer, Model 3300) was used to assess the contents of $\mathrm{Zn}, \mathrm{Mn}$, and $\mathrm{Fe}$ in plant leaves as described in [46].

\subsection{Anatomical Features}

Leaf and stem specimens were secured from the middle internode with its leaf blade. The selected specimens were chosen from plants at the flowering stage for killing and fixing for $48 \mathrm{~h}$ in $100 \mathrm{~mL}$ of F.A.A. solution containing $50 \mathrm{~mL}$ of $\mathrm{C}_{2} \mathrm{H}_{5} \mathrm{OH}(95 \%), 5 \mathrm{~mL}$ of glacial acetic acid, $10 \mathrm{~mL}$ of formalin, in addition to $35 \mathrm{~mL}$ of distilled water. Then, samples were exposed to washing using $\mathrm{C}_{2} \mathrm{H}_{5} \mathrm{OH}(50 \%)$. Dehydration and clearance were then performed with normal butyl alcohol series, and embedded in paraffin wax $\left(54-56{ }^{\circ} \mathrm{C}\right.$ m.p). A rotary microtome was functioned to cut samples for $20 \mu \mathrm{m}$ thick cross-sections that were adhesive (Haupt's adhesive). The samples were then stained with the crystal violet-erythrosin combination [47]. Slide photography was performed and then read by micrometric eye lens to obtain various anatomical features expressed in $\mu \mathrm{m}$.

\subsection{Data Analysis}

The GLM procedure of Gen Stat (version 11) (VSN International Ltd., Oxford, UK) was used to analyze the experimental data. The homogeneity test of error variance was conducted as stated in a method described by Gomez and Gomez [47]. Data from the two seasons were subjected to a combined analysis and, among the means, differences were compared by Duncan's Multiple Range Test at $5 \%$ probability $(p \leq 0.05)$ level.

\section{Results}

\subsection{Changes in Eggplant Growth by Foliar-Applied ZnO NP and Deficit Irrigation}

Eggplant growth in terms of plant height, number of leaves per plant, stem diameter, fresh and dry weights of plant shoot, and total plant leaf area were significantly impacted by $\mathrm{ZnO} N P$ foliar application under deficit irrigation (DI) stress (Table 5). In this respect, DI reduced plant height by $16.3 \%$, leaves number by $23.7 \%$, stem diameter by $7.7 \%$, shoot fresh weight by $25.8 \%$, shoot dry weight $24.2 \%$, and leaf area by $27.4 \%$ compared with fully irrigated plants. These growth traits significantly increased by foliar application of $\mathrm{ZnO} \mathrm{NP}$ and these improvements were more pronounced under $\mathrm{ZnO} \mathrm{NP}(100)$. Exogenous application of ZnO NP alleviated the adverse impacts of DI stress on eggplant growth, in the sense that spraying with $\mathrm{ZnO} N P$ (50 or $100 \mathrm{ppm}$ ) to plants grown under DI gave similar or higher values than those growing under full irrigation without $\mathrm{ZnO} N P$ supply $\left(\mathrm{FI}+\mathrm{ZnO} \mathrm{NP}_{(0)}\right)$. 
Table 5. Effects of foliar application with $\mathrm{ZnO}$ nanoparticles ( $\mathrm{ZnO} \mathrm{NP}$ ) on vegetative growth of eggplant grown under full (FI) and deficit (DI) irrigation.

\begin{tabular}{|c|c|c|c|c|c|c|}
\hline Treatments & $\begin{array}{l}\text { Shoot Length } \\
\text { (cm) }\end{array}$ & $\begin{array}{l}\text { Number of } \\
\text { Leaves }\end{array}$ & $\begin{array}{l}\text { Stem Diameter } \\
(\mathrm{cm})\end{array}$ & $\begin{array}{l}\text { Shoot FW } \\
\text { Plant }^{-1} \text { (g) }\end{array}$ & $\begin{array}{l}\text { Shoot DW } \\
\text { Plant }^{-1}(\mathrm{~g})\end{array}$ & $\begin{array}{c}\text { Leaf Area } \\
\text { Plant }^{-1}\left(\mathrm{dm}^{2}\right)\end{array}$ \\
\hline Irrigation (I) & $*$ & * & ns & * & * & $*$ \\
\hline FI & $88.1 \pm 1.9 \mathrm{a}$ & $61.6 \pm 2.5 \mathrm{a}$ & $1.3 \pm 0.03 \mathrm{a}$ & $283.9 \pm 15.6 \mathrm{a}$ & $55.4 \pm 3.3 \mathrm{a}$ & $55.5 \pm 2.8 \mathrm{a}$ \\
\hline DI & $73.7 \pm 2.7 b$ & $47.0 \pm 3.3 b$ & $1.2 \pm 0.06 \mathrm{~b}$ & $210.7 \pm 10.9 \mathrm{~b}$ & $42.0 \pm 3.4 b$ & $40.3 \pm 2.6 b$ \\
\hline $\mathrm{ZnO} \mathrm{NP}(\mathrm{ppm})$ & $*$ & * & $*$ & $*$ & * & * \\
\hline $\mathrm{ZnONP}(0)$ & $70.8 \pm 3.3 c$ & $45.2 \pm 3.4 b$ & $1.1 \pm 0.07 \mathrm{c}$ & $185.2 \pm 7.4 \mathrm{c}$ & $37.0 \pm 3.6 \mathrm{c}$ & $34.1 \pm 1.8 \mathrm{c}$ \\
\hline $\mathrm{ZnO} \mathrm{NP}(50)$ & $81.0 \pm 2.3 b$ & $55.0 \pm 4.3 \mathrm{a}$ & $1.2 \pm 0.04 b$ & $244.6 \pm 13.6 \mathrm{~b}$ & $47.6 \pm 3.2 \mathrm{~b}$ & $50.8 \pm 3.4 b$ \\
\hline $\mathrm{ZnO} \mathrm{NP}_{(100)}$ & $90.8 \pm 2.4 \mathrm{a}$ & $62.7 \pm 3.3 \mathrm{a}$ & $1.4 \pm 0.04 \mathrm{a}$ & $312.0 \pm 15.3 \mathrm{a}$ & $61.4 \pm 3.7 \mathrm{a}$ & $58.9 \pm 2.5 \mathrm{a}$ \\
\hline $\mathrm{I} \times \mathrm{ZnONP}$ & $* *$ & $* *$ & $* *$ & $* *$ & $* *$ & $* *$ \\
\hline $\mathrm{FI} \times \mathrm{ZnO} \mathrm{NP}(0)$ & $80.8 \pm 2.2 b c$ & $52.5 \pm 1.3 \mathrm{bc}$ & $1.3 \pm 0.11 \mathrm{ab}$ & $206.0 \pm 5.1 \mathrm{~d}$ & $46.1 \pm 3.9 \mathrm{bc}$ & $39.8 \pm 0.9 c$ \\
\hline $\mathrm{FI} \times \mathrm{ZnO} \mathrm{NP}(50)$ & $85.8 \pm 1.2 \mathrm{~b}$ & $67.0 \pm 4.4 \mathrm{a}$ & $1.3 \pm 0.10 \mathrm{ab}$ & $286.5 \pm 10.7 b$ & $55.2 \pm 4.7 \mathrm{ab}$ & $61.4 \pm 2.4 \mathrm{a}$ \\
\hline $\mathrm{FI} \times \mathrm{ZnO} \mathrm{NP}_{(100)}$ & $97.5 \pm 1.5 \mathrm{a}$ & $65.2 \pm 4.2 \mathrm{a}$ & $1.4 \pm 0.04 \mathrm{a}$ & $359.2 \pm 11.3 \mathrm{a}$ & $64.9 \pm 5.9 \mathrm{a}$ & $65.3 \pm 0.4 \mathrm{a}$ \\
\hline $\mathrm{DI} \times \mathrm{ZnONP}(0)$ & $60.7 \pm 1.7 \mathrm{~d}$ & $37.8 \pm 5.2 \mathrm{~d}$ & $1.0 \pm 0.08 \mathrm{c}$ & $164.3 \pm 6.4 \mathrm{e}$ & $28.0 \pm 2.9 \mathrm{~d}$ & $28.3 \pm 0.4 \mathrm{~d}$ \\
\hline $\mathrm{DI} \times \mathrm{ZnO} \mathrm{NP}_{(50)}^{(0)}$ & $76.2 \pm 3.4 \mathrm{bc}$ & $43.0 \pm 1.9 \mathrm{~cd}$ & $1.1 \pm 0.06 \mathrm{bc}$ & $202.8 \pm 1.3 \mathrm{~d}$ & $40.1 \pm 0.3 c$ & $40.3 \pm 0.5 c$ \\
\hline $\mathrm{DI} \times \mathrm{ZnO} \mathrm{NP}(100)$ & $84.2 \pm 2.3 b$ & $60.2 \pm 5.4 \mathrm{ab}$ & $1.4 \pm 0.07 \mathrm{a}$ & $264.8 \pm 11.6 c$ & $57.9 \pm 4.6 \mathrm{ab}$ & $52.4 \pm 3.2 \mathrm{~b}$ \\
\hline
\end{tabular}

** and * indicate, respectively, differences at $p \leq 0.05$ and $p \leq 0.01$ probability level, and "ns" indicates not significant difference. Means followed by the same letter in each column are not significantly different according to Duncan's multiple range test $(p \leq 0.05)$.

\subsection{Changes in Photosynthetic Efficiency and Tissue Water Status by Foliar-Applied ZnO NP and Deficit Irrigation}

Performance index (PI) of the photosynthetic efficiency and relative chlorophyll index (SPAD) were decreased by $22.2 \%$ and $5.9 \%$, respectively, under DI (60\% of ETc) compared to plants grown under FI (Table 6). Comparing non-treated ZnO NP plants, the maximum quantum yield PSII of photochemistry $\left(F_{v} / F_{m}\right)$, PI, and SPAD value were increased with ZnO NP (50 or 100 ppm). Application of ZnO NP (50 or 100 ppm) to drought-stressed plants increased $F_{v} / F_{m}, \mathrm{PI}$, and SPAD value and recorded similar values to nontreated FI plants. Eggplant water status in terms of RWC and MSI were negatively influenced by water stress with $40 \%$. However, both RWC and MSI were increased by $11.3 \%$ and $4.8 \%$ (on average), respectively, in $\mathrm{ZnO} \mathrm{NP}$-treated plants compared to those nontreated (Table 6). Spraying ZnO NP (50 or $100 \mathrm{ppm}$ ) alleviated the adverse effects of drought stress via increasing RWC and MSI as those observed under FI without ZnO NP application (Table 6).

Table 6. Effects of foliar application with $\mathrm{ZnO}$ nanoparticles $(\mathrm{ZnO} N \mathrm{~N})$ on photosynthetic efficiency $\left(F_{v} / F_{m}\right.$, and PI), relative chlorophyll content (SPAD value), relative water content (RWC), and membrane stability index (MSI) of eggplant grown under full (FI) and deficit (DI) irrigation.

\begin{tabular}{|c|c|c|c|c|c|}
\hline Treatments & $F_{v} / F_{m}$ & PI & SPAD Value & RWC\% & MSI\% \\
\hline Irrigation (I) & $\mathrm{ns}$ & $*$ & $*$ & $*$ & $*$ \\
\hline FI & $0.84 \pm 0.00 \mathrm{a}$ & $10.8 \pm 0.29 a$ & $60.9 \pm 0.38 a$ & $78.8 \pm 0.99 \mathrm{a}$ & $77.5 \pm 0.29 \mathrm{a}$ \\
\hline DI & $0.84 \pm 0.00 \mathrm{a}$ & $8.4 \pm 0.38 b$ & $57.3 \pm 0.99 b$ & $73.5 \pm 1.37 \mathrm{~b}$ & $74.7 \pm 0.83 b$ \\
\hline $\mathrm{ZnO} \mathrm{NP}(\mathrm{ppm})$ & $*$ & $*$ & $*$ & $*$ & $*$ \\
\hline $\mathrm{ZnONP}(0)$ & $0.83 \pm 0.00 \mathrm{~b}$ & $8.2 \pm 0.51 c$ & $56.4 \pm 1.3 c$ & $70.8 \pm 1.50 c$ & $73.7 \pm 0.90 b$ \\
\hline $\mathrm{ZnO} \mathrm{NP}(50)$ & $0.84 \pm 0.00 \mathrm{a}$ & $9.7 \pm 0.37 \mathrm{~b}$ & $61.6 \pm 0.61 \mathrm{a}$ & $81.1 \pm 1.30 \mathrm{a}$ & $76.6 \pm 0.66 \mathrm{a}$ \\
\hline $\begin{array}{l}\mathrm{ZnO} \mathrm{NP}(100) \\
\mathrm{I} \times \mathrm{ZnO} \mathrm{NP}\end{array}$ & $\underset{* *}{0.85 \pm 0} 0.00 \mathrm{a}$ & $\underset{* *}{10.9 \pm 0.43 \mathrm{a}}$ & $\begin{array}{c}59.3 \pm 0.40 \mathrm{~b} \\
*\end{array}$ & $\underset{*}{76.5 \pm 0.29 b}$ & $77.9 \pm 0.48 \mathrm{a}$ \\
\hline $\mathrm{FI} \times \mathrm{ZnO} \mathrm{NP}_{(0)}$ & $0.84 \pm 0.00 \mathrm{ab}$ & $9.8 \pm 0.02 b c$ & $60.8 \pm 0.12 \mathrm{ab}$ & $75.7 \pm 0.09 c$ & $76.6 \pm 0.31 \mathrm{ab}$ \\
\hline $\mathrm{FI} \times \mathrm{ZnO} \mathrm{NP}(50)$ & $0.84 \pm 0.00 \mathrm{a}$ & $10.6 \pm 0.62 b$ & $62.4 \pm 0.40 \mathrm{a}$ & $83.8 \pm 0.72 \mathrm{a}$ & $78.6 \pm 0.51 \mathrm{a}$ \\
\hline $\mathrm{FI} \times \mathrm{ZnO} \mathrm{NP}(100)$ & $0.85 \pm 0.00 \mathrm{a}$ & $12.0 \pm 0.28 \mathrm{a}$ & $59.5 \pm 0.63 b$ & $77.0 \pm 1.70 \mathrm{bc}$ & $77.3 \pm 0.31 \mathrm{ab}$ \\
\hline $\mathrm{DI} \times \mathrm{ZnO} \mathrm{NP}(0)$ & $0.83 \pm 0.00 \mathrm{~b}$ & $6.5 \pm 0.24 \mathrm{~d}$ & $52.1 \pm 0.57 c$ & $66.0 \pm 1.09 \mathrm{~d}$ & $70.9 \pm 0.44 c$ \\
\hline $\mathrm{DI} \times \mathrm{ZnO} \mathrm{NP}(50)$ & $0.83 \pm 0.01 \mathrm{a}$ & $8.8 \pm 0.02 c$ & $60.7 \pm 0.57 \mathrm{ab}$ & $78.5 \pm 1.75 \mathrm{~b}$ & $77.3 \pm 1.25 \mathrm{ab}$ \\
\hline $\mathrm{DI} \times \mathrm{ZnO} \mathrm{NP}(100)$ & $0.83 \pm 0.00 \mathrm{a}$ & $9.8 \pm 0.45 b c$ & $59.2 \pm 1.23 \mathrm{~b}$ & $76.0 \pm 0.64 \mathrm{bc}$ & $75.9 \pm 0.85 b$ \\
\hline
\end{tabular}

** and * indicate, respectively, differences at $p \leq 0.05$ and $p \leq 0.01$ probability level, and "ns" indicates not significant difference. Means followed by the same letter in each column are not significantly different according to Duncan's multiple range test $(p \leq 0.05)$. 


\begin{abstract}
3.3. Changes of Eggplant Yield and Water Productivity in Response to Foliar-Applied ZnO NP and Deficit Irrigation

Results of the average length of fruit, individual fruit weight, total number of fruits plant $^{-1}$, total fruit yield, and WP in response to DI, exogenously applied ZnO NP, and their interaction are presented in Table 7. Reducing irrigation down to $60 \%$ ETc significantly decreased fruit length by $9.2 \%$, fruit weight by $18.3 \%$, and the number of fruits plant ${ }^{-1}$ by $8.0 \%$ relative to FI. ZnO NP-treated plants with 50 or $100 \mathrm{ppm} \mathrm{ZnO} \mathrm{NP} \mathrm{showed} \mathrm{the} \mathrm{greatest}$ length and weight of fruit, and total number of fruits plant ${ }^{-1}$ compared to nontreated plants. Spraying $100 \mathrm{ppm} \mathrm{ZnO} \mathrm{NP} \mathrm{to} \mathrm{drought-stressed} \mathrm{eggplant} \mathrm{showed} \mathrm{similar} \mathrm{values}$ of fruit length and average fruit weight to eggplants subjected to FI without $\mathrm{ZnO} \mathrm{NP}$ application $(\mathrm{FI}+\mathrm{ZnO} \mathrm{NP}(0)$ ). However, water-stressed eggplant supplemented with 50 or $100 \mathrm{ppm} Z \mathrm{ZnO} N \mathrm{NP}$ produced higher fruit numbers by $25.6 \%$ and $33.1 \%$, respectively, in comparison with $\mathrm{FI}+\mathrm{ZnO} \mathrm{NP}(0)$.
\end{abstract}

Table 7. Effects of foliar application with $\mathrm{ZnO}$ nanoparticles (ZnO NP) on yield, and water productivity (WP) of eggplant grown under full (FI) and deficit (DI) irrigation.

\begin{tabular}{|c|c|c|c|c|c|}
\hline Treatments & Fruit Length (cm) & $\begin{array}{l}\text { No. of Fruits } \\
\text { Plant }^{-1}\end{array}$ & $\begin{array}{l}\text { Fruit Weight } \\
\text { (g) }\end{array}$ & $\begin{array}{l}\text { Fruit Yield } \\
\quad\left(t \mathrm{ha}^{-1}\right)\end{array}$ & $\begin{array}{c}W P \\
\left(\mathrm{~kg} \mathrm{~m}^{-3}\right)\end{array}$ \\
\hline Irrigation (I) & $*$ & $*$ & $*$ & $*$ & $*$ \\
\hline FI & $14.2 \pm 0.37 \mathrm{a}$ & $17.4 \pm 0.93 \mathrm{a}$ & $67.7 \pm 2.87 \mathrm{a}$ & $51.3 \pm 2.11 \mathrm{a}$ & $7.1 \pm 0.29 b$ \\
\hline DI & $12.9 \pm 0.39 b$ & $16.0 \pm 0.63 b$ & $55.3 \pm 1.27 \mathrm{~b}$ & $42.6 \pm 3.03 b$ & $7.8 \pm 0.58 \mathrm{~b}$ \\
\hline $\mathrm{ZnO} \mathrm{NP}(\mathrm{ppm})$ & $*$ & $*$ & $*$ & $*$ & $*$ \\
\hline $\mathrm{ZnONP}(0)$ & $12.8 \pm 0.59 b$ & $13.5 \pm 0.66 \mathrm{c}$ & $54.7 \pm 2.16 c$ & $34.7 \pm 2.67 c$ & $5.3 \pm 0.25 c$ \\
\hline $\mathrm{ZnO} \mathrm{NP}(50)$ & $14.1 \pm 0.47 \mathrm{a}$ & $17.4 \pm 0.63 b$ & $69.0 \pm 4.29 \mathrm{a}$ & $49.4 \pm 1.84 b$ & $7.9 \pm 0.43 b$ \\
\hline $\mathrm{ZnO} \mathrm{NP}(100)$ & $13.7 \pm 0.38 \mathrm{ab}$ & $19.3 \pm 0.81 \mathrm{a}$ & $60.8 \pm 0.95 b$ & $56.7 \pm 1.85 \mathrm{a}$ & $9.0 \pm 0.30 \mathrm{a}$ \\
\hline $\mathrm{I} \times \mathrm{ZnO} \mathrm{NP}$ & $* *$ & $* *$ & $*$ & $*$ & $*$ \\
\hline $\mathrm{FI} \times \mathrm{ZnO} \mathrm{NP}(0)$ & $14.5 \pm 0.56 \mathrm{ab}$ & $13.3 \pm 0.95 c$ & $58.7 \pm 3.23 b$ & $43.3 \pm 0.99 c$ & $5.9 \pm 0.14 c$ \\
\hline $\mathrm{FI} \times \mathrm{ZnO} \mathrm{NP}_{(50)}$ & $15.2 \pm 0.54 \mathrm{a}$ & $18.2 \pm 0.75 b$ & $82.1 \pm 3.15 a$ & $50.1 \pm 2.31 b$ & $6.9 \pm 0.32 c$ \\
\hline $\mathrm{FI} \times \mathrm{ZnO} \mathrm{NP}(100)$ & $12.8 \pm 0.48 \mathrm{~d}$ & $20.8 \pm 1.25 \mathrm{a}$ & $62.5 \pm 0.93 b$ & $60.3 \pm 3.09 \mathrm{a}$ & $8.3 \pm 0.43 b$ \\
\hline $\mathrm{DI} \times \mathrm{ZnO} \mathrm{NP}(0)$ & $11.2 \pm 0.31 \mathrm{e}$ & $13.7 \pm 0.99 c$ & $50.7 \pm 1.91 c$ & $26.1 \pm 0.88 \mathrm{~d}$ & $4.6 \pm 0.28 \mathrm{~d}$ \\
\hline $\mathrm{DI} \times \mathrm{ZnO} \mathrm{NP}(50)$ & $13.0 \pm 0.45 \mathrm{bd}$ & $16.7 \pm 0.99 b$ & $56.0 \pm 1.83 \mathrm{bc}$ & $48.6 \pm 3.04 \mathrm{bc}$ & $8.9 \pm 0.56 \mathrm{ab}$ \\
\hline $\mathrm{DI} \times \mathrm{ZnO} \mathrm{NP}(100)$ & $14.5 \pm 0.34 \mathrm{abc}$ & $17.7 \pm 0.56 b$ & $59.2 \pm 1.43 b$ & $53.1 \pm 0.53 \mathrm{~b}$ & $9.8 \pm 0.10 \mathrm{a}$ \\
\hline
\end{tabular}

** and * indicate, respectively, differences at $p \leq 0.05$ and $p \leq 0.01$ probability level, and "ns" indicates not significant difference. Means followed by the same letter in each column are not significantly different according to Duncan's multiple range test $(p \leq 0.05)$.

Water deficit exposure noticeably decreased fruit yield by $17 \%$ in comparison to FI, fruit yield was also affected by exogenous application of 50 or $100 \mathrm{ppm} \mathrm{ZnO}$ NP that increased by $42.4 \%$ and $63.4 \%$, respectively, compared with $\mathrm{DI} \times \mathrm{ZnO} \mathrm{NP}_{(0)}$. The greatest fruit yield corresponded with the integrative application of $100 \mathrm{ppm} \mathrm{ZnO} \mathrm{NP}$ and FI treatment. However, combined exogenously applied 50 or $100 \mathrm{ppm}$ of ZnO NP and water deficit at $60 \%$ ETc exhibited higher fruit yield by $12.2 \%$ and $22.6 \%$, respectively, than those obtained with $\mathrm{FI}+\mathrm{ZnO} \mathrm{NP}_{(0)}$ treatment. As shown in Figure 2, the regression analysis among fruit yield and $\mathrm{ZnO}$ NP concentration was a curvilinear relationship, indicating increasing fruit yield with increasing $\mathrm{ZnO} N P$ concentration.

Results of Table 7 reported that the WP was significantly influenced by irrigation regimes, supplementation of $\mathrm{ZnO} \mathrm{NP}$, and their interaction. Under $40 \%$ water deficit, WP increased by $9.9 \%$ compared to FI. Whilst, exogenous $\mathrm{ZnO}$ NP application with 50 and $100 \mathrm{ppm}$ increased WP by $49.1 \%$ and $69.8 \%$ compared to $\mathrm{DI} \times \mathrm{ZnO} \mathrm{NP}_{(0)}$. The highest WP were obtained when plants were irrigated with $60 \%$ ETc and foliarly-sprayed with 50 or $100 \mathrm{ppm}$ of $\mathrm{ZnO} \mathrm{NP}$, which led to 50.8-66.1\% increases in WP when compared with FI + $\mathrm{ZnO} \mathrm{NP}(0)$. 


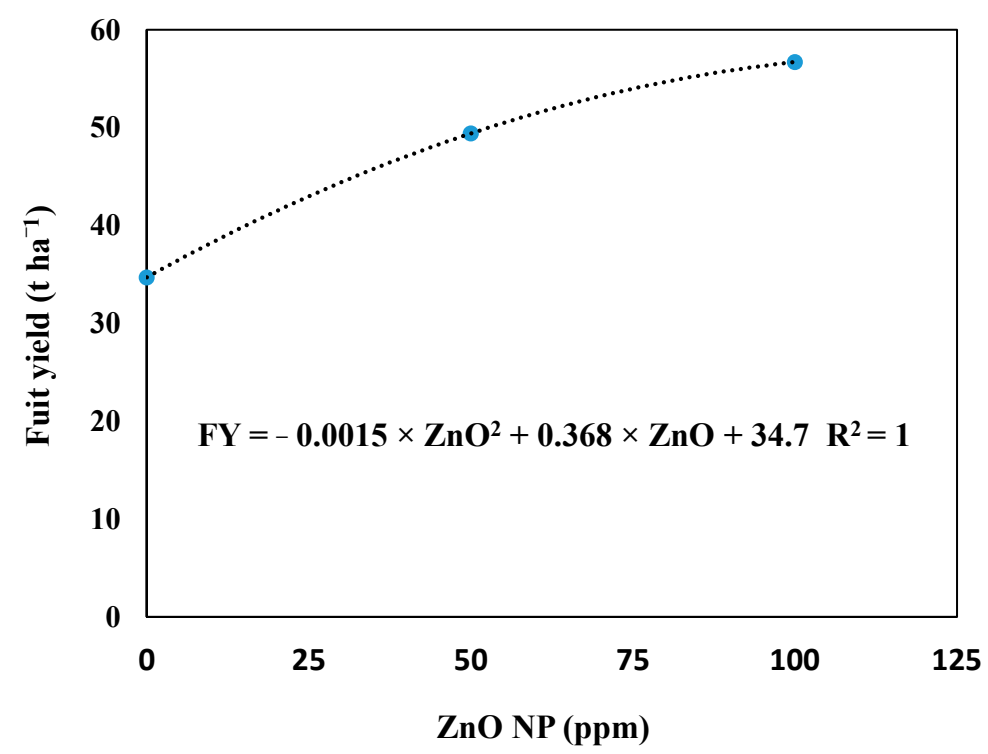

Figure 2. Regression analysis between concentrations of $\mathrm{ZnO}$ nanoparticles ( $\mathrm{ZnO} \mathrm{NP}$ ) and fruit yield $\left(\mathrm{t} \mathrm{ha}{ }^{-1}\right)$ of eggplant.

\subsection{Changes in Nutrients Contents in Response to Foliar-Applied ZnO NP and Deficit Irrigation}

Macronutrients (i.e., $\mathrm{N}$ and $\mathrm{K}$ ) and micronutrients (i.e., $\mathrm{Zn}, \mathrm{Mn}$, and $\mathrm{Fe}$ ) of eggplant leaf tissues were significantly decreased under water shortage by $40 \%$, whereas, P contents were not affected by the irrigation regimes (Table 8). Compared to nontreated $\mathrm{ZnO} \mathrm{NP}$, spraying $\mathrm{ZnO}$ NP (both 50 or $100 \mathrm{ppm}$ ) to eggplant increased their leaf tissue content of macronutrients like N, P, and K and micronutrients like Zn, Mn, and Fe (Table 8). In water-stressed eggplant leaf tissues, the macro and micronutrient concentrations were markedly increased by $\mathrm{ZnO}$ NP supplementation. Among $\mathrm{ZnO} N P$ application, $\mathrm{DI} \times \mathrm{ZnO}$ $\mathrm{NP}_{(100)}$ exhibited higher $\mathrm{N}$ by $21.6 \%$, $\mathrm{P}$ by $91.4 \%$, $\mathrm{K}$ by $9.4 \%$, Zn by $65.0 \%$, Mn by $27 \%$, and Fe $6.6 \%$ when compared with FI $\times \mathrm{ZnO} \mathrm{NP}_{(0)}($ Table 8$)$.

Table 8. Concentrations ( $\mathrm{mg} \mathrm{g}^{-1} \mathrm{DW}$ ) of N, P, K, Zn, Mn, and Fe in eggplant leaves as influenced by foliar application with $\mathrm{ZnO}$ nanoparticles ( $\mathrm{ZnO} \mathrm{NP})$ under full (FI) and deficit (DI) irrigation.

\begin{tabular}{|c|c|c|c|c|c|c|}
\hline Treatments & $\begin{array}{l}\mathrm{N}\left(\mathrm{mg} \mathrm{g}^{-1}\right. \\
\mathrm{DW})\end{array}$ & $P\left(\mathrm{mg} \mathrm{g}^{-1} \mathrm{DW}\right)$ & $\begin{array}{c}\mathrm{K}\left(\mathrm{mg} \mathrm{g}^{-1}\right. \\
\mathrm{DW})\end{array}$ & $\begin{array}{c}\mathrm{Zn}\left(\mathrm{mg} \mathrm{g} \mathrm{g}^{-1}\right. \\
\mathrm{DW})\end{array}$ & $\begin{array}{c}\text { Mn (mg g }{ }^{-1} \\
\text { DW) }\end{array}$ & $\begin{array}{c}\mathrm{Fe}\left(\mathrm{mg} \mathrm{g}^{-1}\right. \\
\text { DW) }\end{array}$ \\
\hline Irrigation (I) & * & ns & $*$ & $*$ & $*$ & $*$ \\
\hline FI & $26.30 \pm 1.6 \mathrm{a}$ & $1.31 \pm 0.10 \mathrm{a}$ & $28.3 \pm 0.81 \mathrm{a}$ & $0.32 \pm 0.03 \mathrm{a}$ & $0.30 \pm 0.01 \mathrm{a}$ & $0.69 \pm 0.03 \mathrm{a}$ \\
\hline DI & $22.30 \pm 1.6 b$ & $1.36 \pm 0.14 \mathrm{a}$ & $23.7 \pm 1.16 b$ & $0.27 \pm 0.03 b$ & $0.25 \pm 0.01 b$ & $0.57 \pm 0.02 b$ \\
\hline $\mathrm{ZnO} \mathrm{NP}(\mathrm{ppm})$ & $*$ & $*$ & * & $*$ & $*$ & $*$ \\
\hline $\mathrm{ZnONP}(0)$ & $18.90 \pm 1.3 b$ & $0.90 \pm 0.01 c$ & $22.6 \pm 1.30 c$ & $0.18 \pm 0.01 c$ & $0.25 \pm 0.01 c$ & $0.56 \pm 0.02 c$ \\
\hline $\mathrm{ZnO} \mathrm{NP}(50)$ & $26.20 \pm 1.6 \mathrm{a}$ & $1.42 \pm 0.04 b$ & $26.6 \pm 1.50 \mathrm{~b}$ & $0.35 \pm 0.01 b$ & $0.29 \pm 0.01 b$ & $0.68 \pm 0.05 a$ \\
\hline $\begin{array}{l}\mathrm{ZnO} \mathrm{NP}(100) \\
\mathrm{I} \times \mathrm{ZnO} \mathrm{NP}\end{array}$ & $27.80 \pm 1.2 \mathrm{a}$ & $\underset{* *}{1.68 \pm 0.07 \mathrm{a}}$ & $\underset{*}{28.8 \pm 0.46} \mathrm{a}$ & $0.36 \pm \underset{* *}{0.01} \mathrm{a}$ & $\begin{array}{c}0.30 \pm 0.01 \mathrm{a} \\
*\end{array}$ & $0.66 \pm 0.00 \mathrm{~b}$ \\
\hline $\mathrm{FI} \times \mathrm{ZnO} \mathrm{NP}(0)$ & $21.30 \pm 1.6 \mathrm{bc}$ & $0.93 \pm 0.02 c$ & $25.4 \pm 0.67 c$ & $0.20 \pm 0.00 \mathrm{~d}$ & $0.26 \pm 0.00 \mathrm{c}$ & $0.61 \pm 0.01 \mathrm{c}$ \\
\hline $\begin{array}{c}\mathrm{FI} \times \mathrm{ZnO} \\
\mathrm{NP}_{(50)}\end{array}$ & $28.10 \pm 2.6 \mathrm{a}$ & $1.43 \pm 0.02 b$ & $29.7 \pm 1.04 \mathrm{a}$ & $0.38 \pm 0.00 \mathrm{~b}$ & $0.32 \pm 0.00 \mathrm{~b}$ & $0.80 \pm 0.00 \mathrm{a}$ \\
\hline $\begin{array}{c}\mathrm{FI} \times \mathrm{ZnO} \\
\mathrm{NP}_{(100)}\end{array}$ & $29.60 \pm 1.0 \mathrm{a}$ & $1.57 \pm 0.02 b$ & $29.8 \pm 1.20 \mathrm{a}$ & $0.39 \pm 0.00 \mathrm{a}$ & $0.33 \pm 0.00 \mathrm{a}$ & $0.67 \pm 0.00 \mathrm{~b}$ \\
\hline $\mathrm{DI} \times \mathrm{ZnO} \mathrm{NP}(0)$ & $16.60 \pm 0.9 c$ & $0.89 \pm 0.01 c$ & $19.8 \pm 0.31 \mathrm{e}$ & $0.15 \pm 0.00 \mathrm{e}$ & $0.23 \pm 0.01 \mathrm{e}$ & $0.51 \pm 0.02 \mathrm{e}$ \\
\hline $\begin{array}{c}\mathrm{DI} \times \mathrm{ZnO} \\
\mathrm{NP}_{(50)}\end{array}$ & $24.40 \pm 1.6 \mathrm{ab}$ & $1.42 \pm 0.08 \mathrm{~b}$ & $23.6 \pm 0.21 \mathrm{~d}$ & $0.33 \pm 0.01 \mathrm{c}$ & $0.26 \pm 0.01 \mathrm{~d}$ & $0.56 \pm 0.00 \mathrm{~d}$ \\
\hline $\begin{array}{c}\mathrm{DI} \times \mathrm{ZnO} \\
\mathrm{NP}_{(100)}\end{array}$ & $25.90 \pm 1.6 \mathrm{ab}$ & $1.78 \pm 0.12 \mathrm{a}$ & $27.8 \pm 0.31 b$ & $0.33 \pm 0.00 \mathrm{c}$ & $0.27 \pm 0.00 \mathrm{c}$ & $0.65 \pm 0.00 \mathrm{~b}$ \\
\hline
\end{tabular}

** and * indicate, respectively, differences at $p \leq 0.05$ and $p \leq 0.01$ probability level, and "ns" indicates not significant difference. Means followed by the same letter in each column are not significantly different according to Duncan's multiple range test $(p \leq 0.05)$. 


\subsection{Leaf and Stem Anatomical Responses to Foliar-Applied ZnO NP and Deficit Irrigation}

Data presented in Tables 9 and 10 and Figures 3 and 4 exhibited that leaf blade thickness, length and thickness of midvein, length and width of the vascular bundle were decreased under $\mathrm{DI} \times \mathrm{ZnO} \mathrm{NP}(0)$. However, exogenous application of $100 \mathrm{ppm} \mathrm{ZnO}$ $\mathrm{NP}$ mitigated the detrimental impacts of DI stress on eggplant, in the view of recorded higher or similar values of leaf anatomical traits when compared with $\mathrm{FI} \times \mathrm{ZnO} \mathrm{NP}(0)$. The greatest stem anatomy characteristics like length and width of stem, length and width of vascular cylinder, dimensions of the pith (length and width), cortex thickness, and vascular cylinder thickness were recorded with $\mathrm{FI} \times \mathrm{ZnO} \mathrm{NP}(100)$, while the lowest values corresponded with $\mathrm{DI} \times \mathrm{ZnO} \mathrm{NP}_{(0)}$ (Table 10 and Figure 4). However, $\mathrm{ZnO} \mathrm{NP}(100 \mathrm{ppm})$ foliar application improved anatomical characteristics of DI plant's stem when compared with FI $\times \mathrm{ZnO} \mathrm{NP}_{(0)}$.

Table 9. Effects of foliar application with $\mathrm{ZnO}$ nanoparticles ( $\mathrm{ZnO} \mathrm{NP}$ ) on leaf anatomy of eggplant grown under full (FI) and deficit (DI) irrigation.

\begin{tabular}{|c|c|c|c|c|c|}
\hline Treatments & $\begin{array}{c}\text { Leaf Blade } \\
\text { Thickness }(\mu \mathrm{m})\end{array}$ & $\begin{array}{l}\text { Midvein Length } \\
(\mu \mathrm{m})\end{array}$ & $\begin{array}{c}\text { Midvein } \\
\text { Thickness }(\mu \mathrm{m})\end{array}$ & $\begin{array}{l}\text { Vascular Bundle } \\
\text { Length }(\mu \mathrm{m})\end{array}$ & $\begin{array}{c}\text { Vascular Bundle } \\
\text { Width }(\mu \mathrm{m})\end{array}$ \\
\hline $\mathrm{I} \times \mathrm{ZnO} \mathrm{NP}$ & $*$ & $*$ & $*$ & $*$ & $*$ \\
\hline $\mathrm{FI} \times \mathrm{ZnO} \mathrm{NP}_{(0)}$ & 200 & 3625 & 3000 & 2050 & 750 \\
\hline $\mathrm{FI} \times \mathrm{ZnO} \mathrm{NP}(50)$ & 175 & 3375 & 3000 & 1875 & 625 \\
\hline $\mathrm{FI} \times \mathrm{ZnO} \mathrm{NP}(100)$ & 200 & 4000 & 3750 & 2400 & 875 \\
\hline $\mathrm{DI} \times \mathrm{ZnO} \mathrm{NP}(0)$ & 175 & 2875 & 2500 & 1500 & 625 \\
\hline $\mathrm{DI} \times \mathrm{ZnO} \mathrm{NP}_{(50)}$ & 225 & 3250 & 3175 & 1750 & 750 \\
\hline $\mathrm{DI} \times \mathrm{ZnO} \mathrm{NP}(100)$ & 250 & 3500 & 3375 & 1875 & 750 \\
\hline
\end{tabular}

* indicate respectively differences at $p \leq 0.05$ probability level, and "ns" indicates not significant difference. Means followed by the same letter in each column are not significantly different according to Duncan's multiple range test $(p \leq 0.05)$.

Table 10. Effects of foliar application with $\mathrm{ZnO}$ nanoparticles ( $\mathrm{ZnO} \mathrm{NP}$ ) on stem anatomy of eggplant grown under full (FI) and deficit (DI) irrigation.

\begin{tabular}{|c|c|c|c|c|c|c|c|c|}
\hline \multirow[t]{2}{*}{ Treatments } & \multicolumn{2}{|c|}{$\begin{array}{l}\text { Dimensions of } \\
\text { Stem }(\mu \mathrm{m})\end{array}$} & \multicolumn{2}{|c|}{$\begin{array}{c}\text { Dimensions of } \\
\text { Vascular Cylinder }(\mu \mathrm{m})\end{array}$} & \multicolumn{2}{|c|}{$\begin{array}{c}\text { Dimensions of } \\
\text { Pith }(\mu \mathrm{m})\end{array}$} & \multirow{2}{*}{$\begin{array}{c}\text { Cortex } \\
\text { Thickness }(\mu \mathrm{m})\end{array}$} & \multirow{2}{*}{$\begin{array}{c}\text { Vascular } \\
\text { Cylinder } \\
\text { Thickness }(\mu \mathrm{m})\end{array}$} \\
\hline & Length & Width & Length & Width & Length & Width & & \\
\hline $\mathrm{I} \times \mathrm{ZnONP}$ & $*$ & $*$ & $*$ & $*$ & $*$ & $*$ & $*$ & $*$ \\
\hline $\mathrm{FI} \times \mathrm{ZnO} \mathrm{NP}_{(0)}$ & 5000 & 4875 & 3625 & 3375 & 2375 & 1750 & 625 & 625 \\
\hline $\mathrm{FI} \times \mathrm{ZnO} \mathrm{NP}(50)$ & 5450 & 4750 & 4050 & 3325 & 3125 & 2350 & 700 & 500 \\
\hline $\mathrm{FI} \times \mathrm{ZnO} \mathrm{NP}(100)$ & 6250 & 6125 & 4500 & 4250 & 3500 & 2750 & 925 & 550 \\
\hline $\mathrm{DI} \times \mathrm{ZnO} \mathrm{NP}(0)$ & 3825 & 3750 & 2875 & 2450 & 2400 & 1750 & 575 & 375 \\
\hline $\mathrm{DI} \times \mathrm{ZnO} \mathrm{NP}(50)$ & 4625 & 4375 & 3250 & 2875 & 2375 & 2250 & 750 & 400 \\
\hline $\mathrm{DI} \times \mathrm{ZnO} \mathrm{NP}(100)$ & 6050 & 5200 & 4325 & 4000 & 3375 & 3125 & 900 & 500 \\
\hline
\end{tabular}

* indicate respectively differences at $p \leq 0.05$ probability level, and "ns" indicates not significant difference. Means followed by the same letter in each column are not significantly different according to Duncan's multiple range test $(p \leq 0.05)$. 

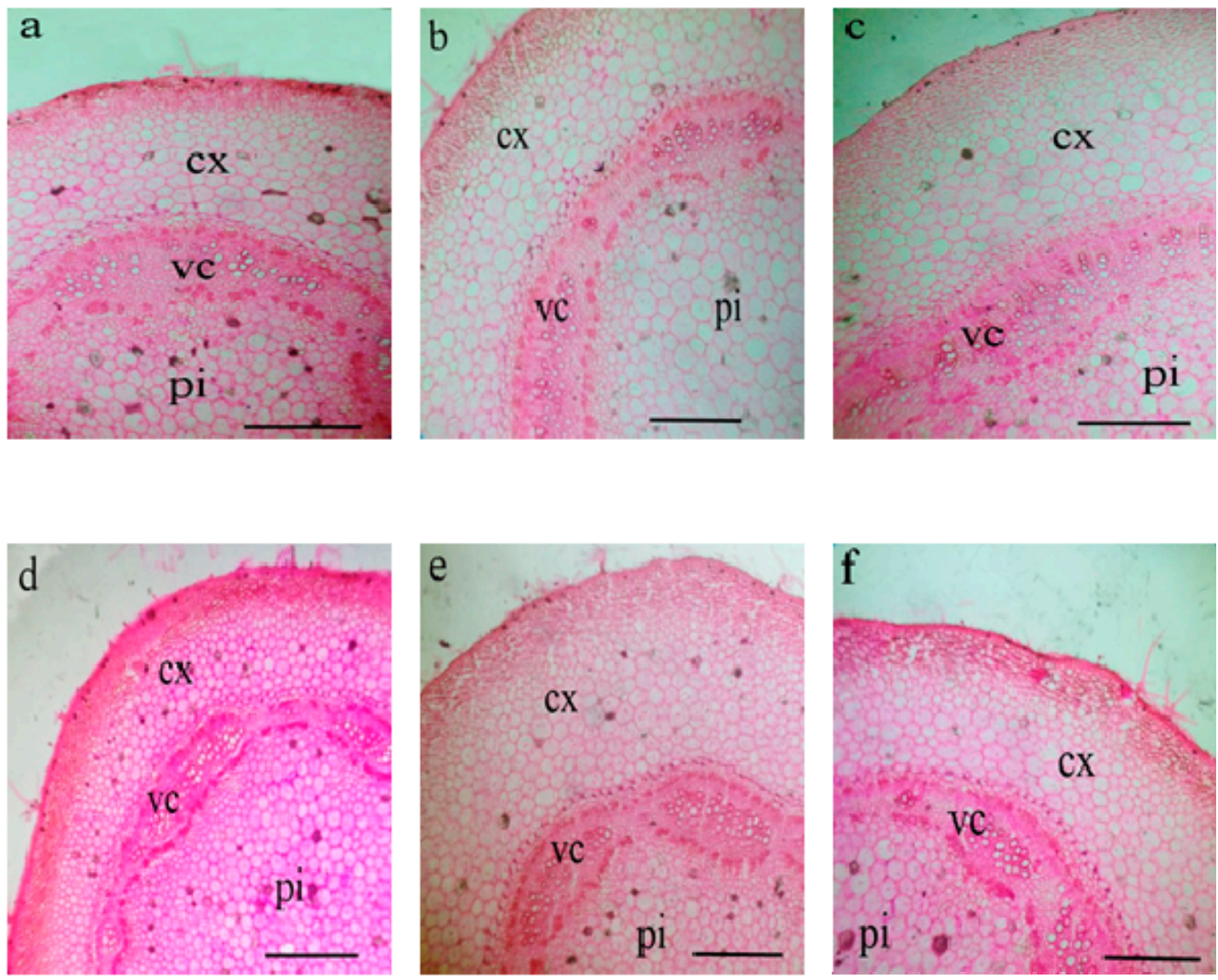

Figure 3. Transverse section in eggplant stem as influenced by foliar application with ZnO nanoparticles (ZnO NP) under full (FI) and deficit (DI) irrigation. (a) $\mathrm{FI} \times \mathrm{ZnO} \mathrm{NP}_{(0)},(\mathbf{b}) \mathrm{FI} \times \mathrm{ZnO} \mathrm{NP}_{(50)},(\mathbf{c}) \mathrm{FI} \times \mathrm{ZnO} \mathrm{NP}(100),(\mathbf{d}) \mathrm{DI} \times \mathrm{ZnO} \mathrm{NP}_{(0)},(\mathbf{e})$ $\mathrm{DI} \times \mathrm{ZnONP}_{(50)},(\mathbf{f}) \mathrm{DI} \times \mathrm{ZnO} \mathrm{NP}_{(100)}$. Scale bar $=350 \mu \mathrm{m}$. $(\mathrm{cx}=$ cortex, $\mathrm{vc}=$ vascular cylinder, $\mathrm{pi}=$ pith $)$.
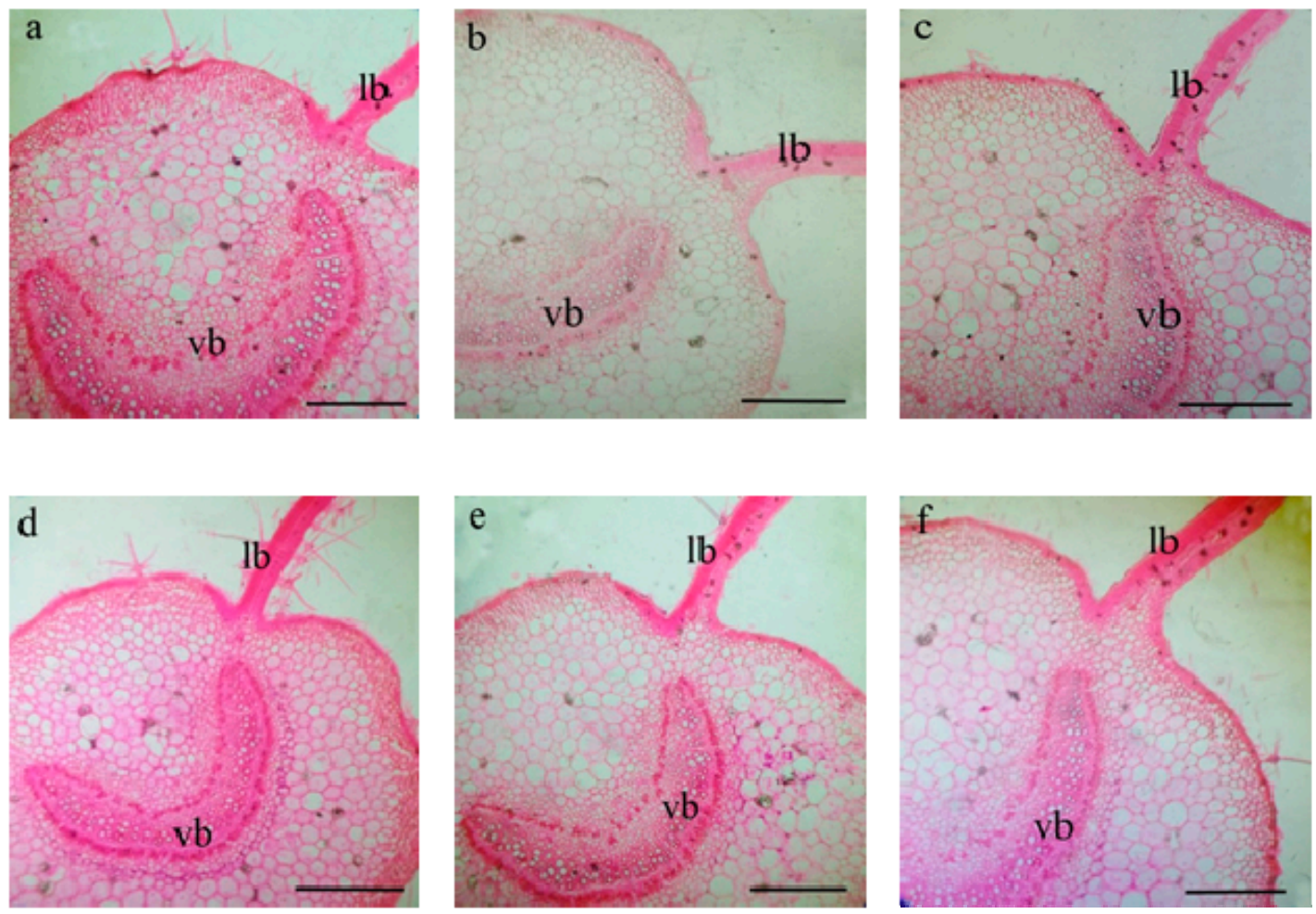

Figure 4. Transverse section in eggplant leaf as influenced by foliar application with ZnO nanoparticles (ZnO NP) under full (FI) and deficit (DI) irrigation. (a) $\mathrm{FI} \times \mathrm{ZnO} \mathrm{NP}_{(0)},(\mathbf{b}) \mathrm{FI} \times \mathrm{ZnO} \mathrm{NP}_{(50)}, \mathrm{c}: \mathrm{FI} \times \mathrm{ZnO} \mathrm{NP}_{(100)},(\mathbf{d}) \mathrm{DI} \times \mathrm{ZnO} \mathrm{NP}(0),(\mathbf{e}) \mathrm{DI}$ $\times \mathrm{ZnO} \mathrm{NP}_{(50)},(\mathbf{f}) \mathrm{DI} \times \mathrm{ZnO} \mathrm{NP}_{(100)}$. Scale bar $=350 \mu \mathrm{m}$. (lb = leaf blade, $\mathrm{vb}=$ vascular bundle $)$. 


\section{Discussion}

Drought is among the main constraints in irrigated agriculture, seriously affecting crop production, thus threatening food security $[7,48]$. These threats to the sustainability of food production are exacerbated by increasing drought episodes in arid regions, including Egypt, particularly when synchronized with salt-alkaline soil [49-51]. The combination of salinity-drought stress could limit plant growth via affecting several physio-biochemical processes and causing nutrients deficiencies. Therefore, these stressors could produce significant yield losses. Engineering of adjuvants in the formulation of nanoparticles such as ZnO NP are being deemed as fertilizers, as well as may confer drought stress tolerance [32,34].

The current study demonstrated that reducing irrigation up to $60 \%$ of ETc resulted in exposure of eggplant to continuous severe water-deficit. This water stress induced losses of membrane integrity and tissue water deficiency, as well as disturbed the photosynthetic capacity of PSII and reduced the relative chlorophyll content (Table 6), which in turn produced substantial impairment of growth-related traits i.e., shoot length, number of leaves plant ${ }^{-1}$, stem diameter, shoot fresh and dry weights, and total plant leaf area (Table 5). A primary response to soil water-deficits is stomatal closure directed via root-toshoot signals (mainly ABA), directly impacting $\mathrm{CO}_{2}$ diffusion into leaf tissues that reduce photosynthesis and diminish eggplant growth [52-54]. Stressors like drought and salinity severely inhibit plant growth and productivity via inducing downregulation of the activity of cyclin-dependent kinase enzymes resulting in fewer meristematic cells and cell division and expansion [55-59], in turn reduced numbers of leaves and leaf area (Table 5), coinciding with reduction of relative chlorophyll index and the photosynthetic efficiency of PSII (Table 6). Our results demonstrated that exogenously applied ZnO NP improved growthrelated parameters of drought-stressed eggplants. This growth-promotion in $\mathrm{ZnO} \mathrm{NP}-$ treated plants is most likely related to $\mathrm{ZnO} \mathrm{NP}$ effects on hormonal signals that modulate root architecture for improved plant adaptation to soil water-deficits [32]. Indeed, ZnO NP enhance gene activity/expression related hormones like ABA and cytokinins, concomitant with regulation of root growth that helped tolerate the drought stress [60]. Moreover, foliar spraying ZnO NP may enhance the restoration of the photosynthetic efficiency, therefore may provide more metabolites/photosynthesis for eggplant growth.

Reduction of available water in the soil and pilling up salts in the soil triggers the accumulation of abscisic acid (ABA) in plant tissues, inducing osmotic stress $[16,61,62]$, and mediated loss of cell turgor due to the lower water availability for cell expansion, thus decreasing the RWC. Furthermore, the reduction of MSI observed in DI-stressed eggplant, may be attributed to the oxidative stress stimulated by excess production of reactive oxygen species (ROS) in plant organelles [50,63,64], inducing lipid peroxidation resulting in a reduction of membrane integrity and loss of cell turgor, indicating that the DI-stressed eggplant leaves experienced cell membrane disintegration [65-67]. However, drought-induced damage to cell membrane and reduction of tissue water content was relieved by exogenous-ZnO NP (Table 5), that agrees with those observed by [68] in maize. Eggplant tissue water status promoted in water-stressed plants by foliar spraying ZnO NP proved that $\mathrm{ZnO} \mathrm{NP}$ may play a role in maintaining cell membrane integrity and increasing RWC as metabolically available water, which could reflect the metabolic processes in plants [69].

Besides decreases of leaf chlorophyll index (SPAD), severe water stress decreased photosynthetic efficiency like the maximum quantum yield of PSII $\left(F_{v} / F_{m}\right)$ and the electron flow rate through PSII (PI; Table 6). Chlorophyll concentration is related to the photosynthetic efficiency [70-72], therefore, the reduction observed in photosynthetic efficiency was associated with chlorophyll degradation [12,73], as occurred in the present study (Table 6). Water-deficits induce degradation of D1 protein that translates into a lower value of $F_{v} / F_{m}$ that represents photoinhibition [74], indicating that the damage occurred in the light-harvesting complex of PSII in drought-stressed eggplant. According to our results, exogenous $\mathrm{ZnO} N \mathrm{NP}$ improved eggplant drought stress tolerance, showing that $\mathrm{ZnO}$ 
NP increased SPAD value concurrently with the increase of the chlorophyll fluorescence apparatus (Table 5). These positive findings by foliar-applied ZnO NP may be attributed to stabilizing membrane integrity and increasing the RWC (Table 6) as well as increasing macro- and micronutrients uptake (Table 8) [75] and impeded the chlorophyllase enzyme activity [76] for maintaining the chlorophyll [77], thence increase the photosynthetic efficiency. Along with this line, the authors of [34] reported that application of $100 \mathrm{mg} \mathrm{L}^{-1}$ $\mathrm{ZnO}$ NP promoted stabilization of the ultrastructure of chloroplast and mitochondria of water-stressed maize which helped to increase the photosynthetic efficiency. This might be linked to the accumulation of osmolytes like proline and sugar content for osmotic adjustment function.

In the present study, drought stress decreased fruit yield and its component (Table 7), which agrees with the results obtained for eggplant [15], tomato [51], and cucumber [78]. Accordingly, they found a reduction in the average weight of fruit, total number of plant fruits, and the total fruit yield when the plant was exposed to water stress. Under drought, exogenous $\mathrm{ZnO}$ NP provokes improvements of eggplant water status, the efficiency of PSII, and eggplant growth and biomass that notably reflected on increases in fruit yield and fruit characteristics (number, weight, and length) (Table 7). The favorable results obtained displayed that $100 \mathrm{ppm}$ of $\mathrm{ZnO} \mathrm{NP}$ (as recommended concentration) was more effective, in the sense that the greatest yield was recorded when applied to fully or deficit irrigated plants. Taken together, these results confirm the previous reports [79] finding that plants require micronutrients in addition to macronutrients for higher development and yield potential. Along with these lines, the authors of [25] demonstrated that sorghum grain yield grown under water stress could be increased up to $183 \%$ by $\mathrm{ZnO}$ NP. Under limited water conditions, the main goal is providing considerable water-saving and increasing WP [3], which increased by $9.9 \%$ by DI in the present study, nevertheless, this improvement in WP is up to $66 \%$ by spraying DI-stressed eggplant with ZnO NP (Table 7). In [27] similar findings were reported, indicating that seed and biomass-based WP increased as a result of the supplementation of sunflower plants grown under $50 \%$ of irrigation restriction with $\mathrm{ZnO}$ NP. Supplemental ZnO NP-induced changes in plant root morphology, increased formation of lateral roots [60], and root biomass [25] presumably increasing water uptake.

Our results exhibited that plants grown under water restriction had a lower concentration of N, K, Zn, and Mn, except for P (Table 8). Soil moisture deficit reduces the nutrients diffusion around the roots as well as nutrients uptake due to decreases in active transport, transpiration flux, and membrane permeability [80]. In sorghum plants, application of $\mathrm{ZnO} \mathrm{NP}$ either to soil or foliar pathways increased nutrients (N, P, K, Zn, and Mn) concentration, as occurred in the present study (Table 7) [81]. However, leaf concentration of the macro- and micronutrients was modulated by foliar-application of ZnO NP (particularly for $100 \mathrm{ppm}$, Table 8). Therefore, our results indicated that drought stress has deleterious effects on eggplant nutritional contents, however, exogenous $\mathrm{ZnO} N \mathrm{NP}$ is involved in alleviating these negative impacts. Previous investigations have depicted that $\mathrm{ZnO} N P$ could increase macro- and micronutrients in pinto beans [82] and sorghum [25]. In addition to the improvements in membrane stability and plant water status, the improved eggplant nutritional status by exogenous $\mathrm{ZnO} N P$ makes eggplant able to attenuate the impacts of DI stress on its growth and productivity.

Plant processes involving genetic, physiological, biochemical, and anatomical mechanisms are responsible for crop performance, these functions are related to the plant's internal anatomy structures [83]. These enhanced attributes (i.e., growth, yield, SPAD value, photosynthetic capacity, water relations, and WP and nutrients content) in response to externally applied ZnO NP might be linked with the improved leaf and stem anatomical features (Tables 9 and 10; Figures 3 and 4). ZnO NP foliar application increased leaf and stem anatomical parameters of eggplants grown under deficit irrigation, probably due to improved RWC, cell membrane stability, and nutrients status [75,84]. 


\section{Conclusions}

According to the findings obtained in the current study, zinc oxide nanoparticles (ZnO NP) foliar application could be a promising practice for improving drought stress tolerance in eggplant cultivated in salt-alkaline soil. These positive effects mainly come from the improved acquisition of macro- and micronutrients, increasing relative water content (RWC), alleviating cell membrane damage (MSI), as well as increasing leaf and stem anatomical traits of eggplants. Eggplant supplemented with ZnO NP elevated SPAD value and chlorophyll fluorescence apparatus ( $F v / F m$ and PI). All these factors collectively contributed to better growth and productivity of eggplant grown under deficit irrigation stress. It is important to note that the use of $\mathrm{ZnO} N \mathrm{NP}$ as a foliar spray for eggplant increased water productivity. Thus, our findings gave the utility of using ZnO NP (100 ppm) for ameliorating water stress effects on eggplant production in dry-land agriculture.

Author Contributions: Conceptualization, W.M.S., A.A., G.F.M., T.A.A.E.-M. and S.A.A.E.-M.; Data curation, W.M.S., A.A., G.F.M., T.A.A.E.-M., S.A.A.E.-M., M.M.R. and E.F.A.; Formal analysis, W.M.S., A.A., G.F.M., T.A.A.E.-M. and S.A.A.E.-M.; Investigation, W.M.S., A.A., G.F.M., T.A.A.E.-M., S.A.A.E.M., M.M.R. and E.F.A.; Methodology, W.M.S., A.A., G.F.M. and T.A.A.E.-M.; Resources, W.M.S., A.A., G.F.M., T.A.A.E.-M., S.A.A.E.-M., M.M.R. and E.F.A.; Software, W.M.S., A.A. and T.A.A.E.-M.; Writing-original draft, W.M.S., A.A., G.F.M., T.A.A.E.-M. and S.A.A.E.-M.; Writing-review and editing, W.M.S., M.M.R. and E.F.A. All authors have read and agreed to the published version of the manuscript.

Funding: The Deanship of Scientific Research at Taif University through the research number TURSP$2020 / 65$ is acknowledged.

Institutional Review Board Statement: Not applicable.

Informed Consent Statement: Not applicable.

Data Availability Statement: The data presented in this study are available upon request from the corresponding author.

Acknowledgments: The authors are thankful to Taif University Researchers Supporting Project number (TURSP-2020/65), Taif University, Taif, Saudi Arabia for providing the financial support and research facilities.

Conflicts of Interest: The authors declare no conflict of interest.

\section{References}

1. FAO. Global Information System on Water and Agriculture; Food and Agriculture Organization: Rome, Italy, 2019.

2. Winter, J.M.; Lopez, J.R.; Ruane, A.C.; Young, C.A.; Scanlon, B.R.; Rosenzweig, C. Representing water scarcity in future agricultural assessments. Anthropocene 2017, 18, 15-26. [CrossRef]

3. Fereres, E.; Soriano, M.A. Deficit irrigation for reducing agricultural water use. J. Exp. Bot. 2007, 58, 147-159. [CrossRef]

4. Abdelkhalik, A.; Pascual, B.; Nájera, I.; Baixauli, C.; Pascual-Seva, N. Regulated Deficit Irrigation as a Water-Saving Strategy for Onion Cultivation in Mediterranean Conditions. Agronomy 2019, 9, 521. [CrossRef]

5. Kokina, I.; Plaksenkova, I.; Jermalonoka, M.; Petrova, A. Impact of iron oxide nanoparticles on yellow medick (Medicago falcata L.) plants. J. Plant Interact. 2020, 15, 1-7. [CrossRef]

6. Rady, M.O.A.; Semida, W.M.; El-mageed, T.A.A.; Howladar, S.M.; Shaaban, A. Foliage Applied Selenium Improves Photosynthetic Efficiency, Antioxidant Potential and Wheat Productivity under Drought Stress. Int. J. Agric. Biol. 2020, $24,1293-1300$. [CrossRef]

7. El-Mageed, T.A.A.; Semida, W.M.; Rady, M.M. Moringa leaf extract as biostimulant improves water use efficiency, physiobiochemical attributes of squash plants under deficit irrigation. Agric. Water Manag. 2017, 193, 46-54. [CrossRef]

8. Kirda, C. Deficit Irrigation Scheduling Based on Plant Growth Stages Showing Water Stress Tolerance; Water Reports; FAO: Rome, Italy, 2002; pp. 3-10.

9. Capra, A.; Consoli, S.; Scicolone, B. Deficit irrigation: Theory and practice. In Agricultural Irrigation Research Progress; Alonso, D., Iglesias, H.J., Eds.; Nova Science Publishers: Hauppauge, NY, USA, 2008; pp. 53-82.

10. Levidow, L.; Zaccaria, D.; Maia, R.; Vivas, E.; Todorovic, M.; Scardigno, A. Improving water-efficient irrigation: Prospects and difficulties of innovative practices. Agric. Water Manag. 2014, 146, 84-94. [CrossRef]

11. El-Mageed, T.A.A.; El-Sherif, A.M.; El-Mageed, S.A.A.; Abdou, N.M. A novel compost alleviate drought stress for sugar beet production grown in Cd-contaminated saline soil. Agric. Water Manag. 2019, 226, 105831. [CrossRef] 
12. Rady, M.O.; Semida, W.M.; Howladar, S.; El-Mageed, T.A.A. Raised beds modulate physiological responses, yield and water use efficiency of wheat (Triticum aestivum L.) under deficit irrigation. Agric. Water Manag. 2021, 245, 106629. [CrossRef]

13. Pereira, L.S.; Oweis, T.; Zairi, A. Irrigation management under water scarcity. Agric. Water Manag. 2002, 57, 175-206. [CrossRef]

14. Food and Agriculture Organization. FAOSTAT Food and Agriculture Data; Food and Agriculture Organization: Rome, Italy, 2019.

15. Çolak, Y.B.; Yazar, A.; Gönen, E.; Eroğlu, E. Çağlar Yield and quality response of surface and subsurface drip-irrigated eggplant and comparison of net returns. Agric. Water Manag. 2018, 206, 165-175. [CrossRef]

16. Semida, W.M.; Abd El-Mageed, T.A.; Howladar, S.M.; Mohamed, G.F.; Rady, M.M. Response of Solanum melongena L. seed-lings grown under saline calcareous soil conditions to a new organo-mineral fertilizer. J. Anim. Plant Sci. 2015, 25, 485-493.

17. Díaz-Pérez, J.C.; Eaton, T.E. Eggplant (Solanum melongena L.) Plant Growth and Fruit Yield as Affected by Drip Irrigation Rate. HortScience 2015, 50, 1709-1714. [CrossRef]

18. Plazas, M.; Nguyen, H.T.; González-Orenga, S.; Fita, A.; Vicente, O.; Prohens, J.; Boscaiu, M. Comparative analysis of the responses to water stress in eggplant (Solanum melongena) cultivars. Plant Physiol. Biochem. 2019, 143, 72-82. [CrossRef]

19. Karam, F.; Saliba, R.; Skaf, S.; Breidy, J.; Rouphael, Y.; Balendonck, J. Yield and water use of eggplants (Solanum melongena L.) under full and deficit irrigation regimes. Agric. Water Manag. 2011, 98, 1307-1316. [CrossRef]

20. Vaghar, M.S.; Sayfzadeh, S.; Zakerin, H.R.; Kobraee, S.; Valadabadi, S.A. Foliar application of iron, zinc, and manganese nanochelates improves physiological indicators and soybean yield under water deficit stress. J. Plant Nutr. 2020, 43, 2740-2756. [CrossRef]

21. Davarpanaha, S.; Tehranifara, A.; Davarynejada, G.; Abadía, J.; Khorasanic, R. Effects of foliar applications of zinc and boron nano-fertilizers on pomegranate (Punica granatum cv. Ardestani) fruit yield and quality. Sci. Hortic. 2016, 210, 57-64. [CrossRef]

22. Abbasifar, A.; Shahrabadi, F.; ValizadehKaji, B. Effects of green synthesized zinc and copper nano-fertilizers on the morphological and biochemical attributes of basil plant. J. Plant Nutr. 2020, 43, 1104-1118. [CrossRef]

23. Fernández, V.; Eichert, T. Uptake of Hydrophilic Solutes through Plant Leaves: Current State of Knowledge and Perspectives of Foliar Fertilization. Crit. Rev. Plant Sci. 2009, 28, 36-68. [CrossRef]

24. Karim, R.; Rahman, M.A. Drought risk management for increased cereal production in Asian Least Developed Countries. Weather Clim. Extrem. 2015, 7, 24-35. [CrossRef]

25. Dimkpa, C.O.; Singh, U.; Bindraban, P.S.; Elmer, W.H.; Gardea-Torresdey, J.L.; White, J.C. Zinc oxide nanoparticles alleviate drought-induced alterations in sorghum performance, nutrient acquisition, and grain fortification. Sci. Total Environ. 2019, 688, 926-934. [CrossRef]

26. López-valdez, F.; Fernández-Luqueño, F. Agricultural Nanobiotechnology; López-valdez, F., Fernández-Luqueño, F., Eds.; Springer: Basingstoke, UK, 2018; ISBN 9783319967189.

27. Seghatoleslami, M.; Forutani, R. Yield and Water Use Efficiency of Sunflower as Affected by nano ZnO and Water Stress. J. Adv. Agric. Technol. 2015, 2, 34-37. [CrossRef]

28. Vishekaii, Z.R.; Soleimani, A.; Fallahi, E.; Ghasemnezhad, M.; Hasani, A. The impact of foliar application of boron nano-chelated fertilizer and boric acid on fruit yield, oil content, and quality attributes in olive (Olea europaea L.). Sci. Hortic. 2019, 257, 108689. [CrossRef]

29. Dimkpa, C.O.; Andrews, J.; Fugice, J.; Singh, U.; Bindraban, P.S.; Elmer, W.H.; Gardea-Torresdey, J.L.; White, J.C. Facile Coating of Urea With Low-Dose ZnO Nanoparticles Promotes Wheat Performance and Enhances Zn Uptake Under Drought Stress. Front. Plant Sci. 2020, 11, 168. [CrossRef] [PubMed]

30. Zahedi, S.M.; Karimi, M.; Da Silva, J.A.T. The use of nanotechnology to increase quality and yield of fruit crops. J. Sci. Food Agric. 2020, 100, 25-31. [CrossRef]

31. Sun, L.; Song, F.; Guo, J.; Zhu, X.; Liu, S.; Liu, F. Nano-ZnO-Induced Drought Tolerance Is Associated with Melatonin Syn-thesis and Metabolism in Maize. Int. J. Mol. Sci. 2020, 21, 782. [CrossRef]

32. Smith, D.W. Soil Survey Staff Keys to Soil Taxonomy, 12th ed.; USDA-NRCS: Washington, DC, USA, $2014 ;$ ISBN 0926487221.

33. Page, A.I.; Miller, R.H.; Keeny, D.R. Methods of Soil Analysis. In Part II: Chemical and Microbiological Methods, 2nd ed.; American Society of Agronomy: Madison, WI, USA, 1982; pp. 225-246.

34. Klute, A.; Dirksen, C. Hydraulic Conductivity and Diffusivity: Laboratory Methods. Methods Biogeochem. Wetl. 2018, 9, 687-734. [CrossRef]

35. Allen, R.G.; Pereira, L.S.; Raes, D.; Smith, M. Crop Evapotranspiration: Guidelines for Computing Crop Requirements; FAO Irrigation and Drainage Paper No. 56; FAO: Rome, Italy, 1998.

36. Wallace, D.H.; Munger, H.M. Studies of the Physiological Basis for Yield Differences. I. Growth Analysis of Six Dry Bean Varieties 1. Crop. Sci. 1965, 5, 343-348. [CrossRef]

37. Hayat, S.; Ali, B.; Hasan, S.A.; Ahmad, A. Brassinosteroid enhanced the level of antioxidants under cadmium stress in Brassica juncea. Environ. Exp. Bot. 2007, 60, 33-41. [CrossRef]

38. Premachandra, G.S.; Saneoka, H.; Ogata, S. Cell membrane stability, an indicator of drought tolerance, as affected by ap-plied nitrogen in soyabean. J. Agric. Sci. 1990, 115, 63-66. [CrossRef]

39. Maxwell, K.; Johnson, G.N. Chlorophyll fluorescence-A practical guide. J. Exp. Bot. 2000, 51, 659-668. [CrossRef] [PubMed]

40. Clark, A.; Landolt, W.; Bucher, J.; Strasser, R. Beech (Fagus sylvatica) response to ozone exposure assessed with a chlorophyll a fluorescence performance index. Environ. Pollut. 2000, 109, 501-507. [CrossRef] 
41. Fernández, J.; Alcon, F.; Diaz-Espejo, A.; Hernandez-Santana, V.; Cuevas, M. Water use indicators and economic analysis for on-farm irrigation decision: A case study of a super high density olive tree orchard. Agric. Water Manag. 2020, $237,106074$. [CrossRef]

42. Jensen, M.E. Design and Operation of Farm Irrigation Systems; American Society of Agricultural Engineers: St. Joseph, MI, USA, 1983; p. 827.

43. AOAC. Official Methods of Analysis of AOAC International; Horwitz, W., Ed.; Association of Official Analytical Chemists: Washington, DC, USA, 1995; Volume 2, pp. 1058-1059. ISBN 0935584544.

44. Jackson, M.L. Soil Chemical Analysis: Advanced Course; UW-Madison Libraries Parallel Press: Madison, WI, USA, 2005.

45. Chapman, H.D.; Pratt, P.F. Methods of Analysis for Soil, Plants and Water; Division of Agricultural Science, University of California: Berkeley, CA, USA, 1961.

46. Nassar, M.A.; El-Sahhar, K.F. Botanical Preparations and Microscopy (Microtechnique); Academic Bookshop: Giza, Egypt, 1998.

47. Gomez, K.A.; Gomez, A.A. Statistical Procedures for Agricultural Research, 2nd ed.; John Wiley \& Sons: Singapore, $1984 ;$ p. 680.

48. Abdelkhalik, A.; Pascual, B.; Nájera, I.; Domene, M.A.; Baixauli, C.; Pascual-Seva, N. Effects of deficit irrigation on the yield and irrigation water use efficiency of drip-irrigated sweet pepper (Capsicum annuum L.) under Mediterranean conditions. Irrig. Sci. 2019, 38, 89-104. [CrossRef]

49. El-Mageed, T.A.A.; Semida, W.M.; Taha, R.S.; Rady, M.M. Effect of summer-fall deficit irrigation on morpho-physiological, anatomical responses, fruit yield and water use efficiency of cucumber under salt affected soil. Sci. Hortic. 2018, 237, 148-155. [CrossRef]

50. Rady, M.M.; Belal, H.E.; Gadallah, F.M.; Semida, W.M. Selenium application in two methods promotes drought tolerance in Solanum lycopersicum plant by inducing the antioxidant defense system. Sci. Hortic. 2020, 266, 109290. [CrossRef]

51. Du, T.; Kang, S.; Zhang, J.; Davies, W.J. Deficit irrigation and sustainable water-resource strategies in agriculture for China's food security. J. Exp. Bot. 2015, 66, 2253-2269. [CrossRef]

52. Abdelkhalik, A.; Pascual-Seva, N.; Nájera, I.; Domene, M.Á.; Baixauli, C.; Pascual, B. Effect of Deficit Irrigation on the Productive Response of Drip-irrigated Onion (Allium cepa L.) in Mediterranean Conditions. Hortic. J. 2019, 88, 488-498. [CrossRef]

53. El-Mageed, T.A.A.; Shaaban, A.; El-Mageed, S.A.A.; Semida, W.M.; Rady, M.O.A. Silicon defensive role in maize (Zea mays L.) against drought stress and metals-contaminated irrigation water. Silicon 2020, 1-12. [CrossRef]

54. Shrivastava, P.; Kumar, R. Soil salinity: A serious environmental issue and plant growth promoting bacteria as one of the tools for its alleviation. Saudi J. Biol. Sci. 2015, 22, 123-131. [CrossRef]

55. Zhu, J.-K. Salt and drought stress signal transduction in plants. Annu. Rev. Plant Biol. 2002, 53, 247-273. [CrossRef]

56. Desoky, E.-S.M.; Merwad, A.-R.M.; Rady, M.M. Natural Biostimulants Improve Saline Soil Characteristics and Salt StressedSorghum Performance. Commun. Soil Sci. Plant Anal. 2018, 49, 967-983. [CrossRef]

57. Semida, W.M.; Hemida, K.A.; Rady, M.M. Sequenced ascorbate-proline-glutathione seed treatment elevates cadmium tolerance in cucumber transplants. Ecotoxicol. Environ. Saf. 2018, 154, 171-179. [CrossRef]

58. Rady, M.O.A.; Semida, W.M.; El-Mageed, T.A.A.; Hemida, K.A.; Rady, M.M. Up-regulation of antioxidative defense systems by glycine betaine foliar application in onion plants confer tolerance to salinity stress. Sci. Hortic. 2018, 240, 614-622. [CrossRef]

59. Yang, K.-Y.; Doxey, S.; McLean, J.E.; Britt, D.; Watson, A.; Al Qassy, D.; Jacobson, A.; Anderson, A.J. Remodeling of root morphology by $\mathrm{CuO}$ and $\mathrm{ZnO}$ nanoparticles: Effects on drought tolerance for plants colonized by a beneficial pseudomonad. Bot. 2018, 96, 175-186. [CrossRef]

60. Ahmad, J.; Bashir, H.; Bagheri, R.; Baig, A.; Al-Huqail, A.; Ibrahim, M.M.; Qureshi, M.I. Drought and salinity induced changes in ecophysiology and proteomic profile of Parthenium hysterophorus. PLoS ONE 2017, 12, e0185118. [CrossRef]

61. Upadhyaya, H.; Sahoo, L.; Panda, S.K. Molecular Physiology of Osmotic Stress in Plants. In Molecular Stress Physiology of Plants, Rout, G., Das, A., Eds.; Springer: New Delhi, India, 2013; pp. 179-192. ISBN 978-81-322-0807-5.

62. El-Mageed, T.A.A.; Semida, W.M.; Mohamed, G.F.; Rady, M.M. Combined effect of foliar-applied salicylic acid and deficit irrigation on physiological-anatomical responses, and yield of squash plants under saline soil. S. Afr. J. Bot. 2016, 106, 8-16. [CrossRef]

63. Rady, M.M.; Taha, R.S.; Semida, W.M.; Alharby, H.F. Modulation of salt stress effects on Vicia faba L. plants grown on a re-claimed-saline soil by salicylic acid application. Rom. Agric. Res. 2017, 34, 175-185.

64. Abdelkhalik, A.; Pascual-Seva, N.; Nájera, I.; Giner, A.; Baixauli, C.; Pascual, B. Yield response of seedless watermelon to different drip irrigation strategies under Mediterranean conditions. Agric. Water Manag. 2019, 212, 99-110. [CrossRef]

65. El-Mageed, T.A.A.; Semida, W.M. Effect of deficit irrigation and growing seasons on plant water status, fruit yield and water use efficiency of squash under saline soil. Sci. Hortic. 2015, 186, 89-100. [CrossRef]

66. El-Mageed, T.A.A.; Semida, W.M.; El-Wahed, M.H.A. Effect of mulching on plant water status, soil salinity and yield of squash under summer-fall deficit irrigation in salt affected soil. Agric. Water Manag. 2016, 173, 1-12. [CrossRef]

67. Janmohammadi, M.; Navid, A.; Segherloo, A.E.; Sabaghnia, N. Impact of nano-chelated micronutrients and biological ferti-lizers on growth performance and grain yield of maize under deficit irrigation condition. Biologia 2016, 62, $134-147$.

68. Yan, W.; Zhong, Y.; Shangguan, Z. A meta-analysis of leaf gas exchange and water status responses to drought. Sci. Rep. 2016, 6, 20917. [CrossRef] 
69. Zhao, L.-S.; Li, K.; Wang, Q.-M.; Song, X.-Y.; Su, H.-N.; Xie, B.-B.; Zhang, X.-Y.; Huang, F.; Bai-Cheng, Z.; Zhou, B.-C.; et al. Nitrogen Starvation Impacts the Photosynthetic Performance of Porphyridium cruentum as Revealed by Chlorophyll a Fluorescence. Sci. Rep. 2017, 7, 1-11. [CrossRef]

70. Semida, W.M.; El-Mageed, T.A.A.; Hemida, K.; Rady, M.M. Natural bee-honey based biostimulants confer salt tolerance in onion via modulation of the antioxidant defence system. J. Hortic. Sci. Biotechnol. 2019, 94, 632-642. [CrossRef]

71. Seleiman, M.F.; Semida, W.M.; Rady, M.M.; Mohamed, G.F.; Hemida, K.A.B.A.A.; Hassan, M.M.; Shami, A. Sequential Application of Antioxidants Rectifies Ion Imbalance and Strengthens Antioxidant Systems in Salt-Stressed Cucumber. Plants 2020, 9 , 1783. [CrossRef]

72. De Melo, H.F.; De Souza, E.R.; Cunha, J.C. Fluorescence of chlorophyll and photosynthetic pigments in Atriplex nummularia under abiotic stresses. Rev. Bras. Eng. Agríc. Ambient. 2017, 21, 232-237. [CrossRef]

73. Urban, L.; Aarrouf, J.; Bidel, L.P.R. Assessing the Effects of Water Deficit on Photosynthesis Using Parameters Derived from Measurements of Leaf Gas Exchange and of Chlorophyll a Fluorescence. Front. Plant Sci. 2017, 8, 2068. [CrossRef] [PubMed]

74. El-Mageed, T.A.A.; Rady, M.M.; Taha, R.S.; El Azeam, S.A.; Simpson, C.R.; Semida, W.M. Effects of integrated use of residual sulfur-enhanced biochar with effective microorganisms on soil properties, plant growth and short-term productivity of Capsicum annuum under salt stress. Sci. Hortic. 2020, 261, 108930. [CrossRef]

75. Reddy, M.P. Changes in pigment composition. Hill reaction activity and saccharides metabolism in bajra (Penisetum ty-phoides) leaves under $\mathrm{NaCl}$ salinity. Photosynthetica 1986, 20, 50-55.

76. Dos Santos, E.F.; Zanchim, B.J.; De Campos, A.G.; Garrone, R.F.; Junior, J.L. Photosynthesis rate, chlorophyll content and initial development of physic nut without micronutrient fertilization. Rev. Bras. Ciênc. Solo 2013, 37, 1334-1342. [CrossRef]

77. El-Mageed, T.A.A.; Semida, W.M. Organo mineral fertilizer can mitigate water stress for cucumber production (Cucumis sativus L.). Agric. Water Manag. 2015, 159, 1-10. [CrossRef]

78. Dimkpa, C.O.; Singh, U.; Bindraban, P.S.; Adisa, I.O.; Elmer, W.H.; Gardea-Torresdey, J.L.; White, J.C. Addition-omission of zinc, copper, and boron nano and bulk oxide particles demonstrate element and size -specific response of soybean to micronutrients exposure. Sci. Total Environ. 2019, 665, 606-616. [CrossRef]

79. Etienne, P.; Diquelou, S.; Prudent, M.; Salon, C.; Maillard, A.; Ourry, A. Macro and Micronutrient Storage in Plants and Their Remobilization When Facing Scarcity: The Case of Drought. Agriculture 2018, 8, 14. [CrossRef]

80. Dimkpa, C.O.; White, J.C.; Elmer, W.H.; Gardea-Torresdey, J. Nanoparticle and Ionic Zn Promote Nutrient Loading of Sorghum Grain under Low NPK Fertilization. J. Agric. Food Chem. 2017, 65, 8552-8559. [CrossRef]

81. Grangah, M.F.; Rashidi, V.; Mirshekari, B.; Behrouzyar, E.K.; Farahvash, F. Effects of nano-fertilizers on physiological and yield characteristics of pinto bean cultivars under water deficit stress. J. Plant Nutr. 2020, 43, 2898-2910. [CrossRef]

82. Mangena, P. Water Stress: Morphological and Anatomical Changes in Soybean (Glycine max L.) Plants. In Plant, Abiotic Stress and Responses to Climate Change; Andjelkovic, V., Ed.; IntechOpen: London, UK, 2018.

83. Petrov, P.; Petrova, A.; Dimitrov, I.; Tashev, T.; Olsovska, K.; Brestic, M.; Misheva, S. Relationships between leaf morpho-anatomy, water status and cell membrane stability in leaves of wheat seedlings subjected to severe soil drought. J. Agron. Crop. Sci. 2018, 204, 219-227. [CrossRef]

84. Hafez, Y.; Attia, K.; Alamery, S.; Ghazy, A.; Al-Doss, A.; Ibrahim, E.; Rashwan, E.; El-Maghraby, L.; Awad, A.; Abdelaal, K. Beneficial Effects of Biochar and Chitosan on Antioxidative Capacity, Osmolytes Accumulation, and Anatomical Characters of Water-Stressed Barley Plants. Agronomy 2020, 10, 630. [CrossRef] 